\title{
A high-resolution temporal record of environmental changes in the Eastern Caribbean (Guadeloupe) from 40 to $10 \mathrm{ka}$ BP
}

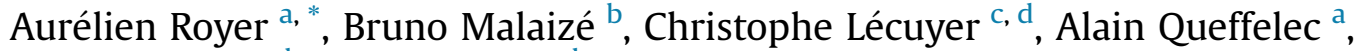 \\ Karine Charlier ${ }^{\mathrm{b}}$, Thibaut Caley ${ }^{\mathrm{b}}$, Arnaud Lenoble ${ }^{\mathrm{a}}$ \\ a Université de Bordeaux, CNRS UMR 5199 PACEA, Bâtiment B18, Allée Geoffroy Saint Hilaire, CS 50023, 33615 Pessac Cedex, France \\ ${ }^{\mathrm{b}}$ Université de Bordeaux, CNRS UMR 5805 EPOC, Bâtiment B18, Allée Geoffroy Saint Hilaire, CS 50023, 33615 Pessac Cedex, France \\ ${ }^{c}$ Université Lyon 1, CNRS UMR 5276 Laboratoire de Géologie de Lyon, et Ecole Normale Supérieure de Lyon, 69622 Villeurbanne, France \\ d Institut Universitaire de France, Paris, France
}

\section{A R T I C L E I N F O}

\section{Article history:}

Received 15 April 2016

Received in revised form

2 November 2016

Accepted 10 November 2016

Available online 25 November 2016

\section{Keywords:}

Caribbean Basin

Last Glacial

Guano

Carbon isotope

Nitrogen isotope

\begin{abstract}
A B S T R A C T
In neotropical regions, fossil bat guano accumulated over time as laminated layers in caves, hence providing a high-resolution temporal record of terrestrial environmental changes. Additionally, cave settings have the property to preserve such organic sediments from processes triggered by winds (deflation, abrasion and sandblasting) and intense rainfall (leaching away). This study reports both stable carbon and nitrogen isotope compositions of frugivorous bat guano deposited in a well-preserved stratigraphic succession of Blanchard Cave on Marie-Galante, Guadeloupe. These isotopic data are discussed with regard to climate changes and its specific impact on Eastern Caribbean vegetation during the Late Pleistocene from 40 to $10 \mathrm{ka}$ cal. BP. Guano $\delta^{13} \mathrm{C}$ values are higher than modern ones, suggesting noticeable vegetation changes. This provides also evidence for overall drier environmental conditions during the Pleistocene compared to today. Meanwhile, within this generally drier climate, shifts between wetter and drier conditions can be observed. Large temporal amplitudes in both $\delta^{13} \mathrm{C}$ and $\delta^{15} \mathrm{~N}$ variations reaching up to $5.9 \%$ and $16.8 \%$, respectively, also indicate these oceanic tropical environments have been highly sensitive to regional or global climatic forcing. Stable isotope compositions of bat guano deposited from 40 to $35 \mathrm{ka}$ BP, the Last Glacial Maximum and the Younger-Dryas reveal relatively wet environmental conditions whereas, at least from the end of the Heinrich event 1 and the Bølling period the region experienced drier environmental conditions. Nevertheless, when considering uncertainties in the model age, the isotopic record of Blanchard Cave show relatively similar variations with known proxy records from the northern South America and Central America, suggesting thus that the Blanchard Cave record is a robust proxy of past ITCZ migration. Teleconnections through global atmospheric pattern suggest that islands of the eastern Caribbean Basin could be also under the influence of a bipolar temperature gradients that impact the mean location of the ITCZ, with a Southern Hemisphere imprint during the glacial period and a more significant role of Northern Hemisphere during the last deglaciation.
\end{abstract}

(C) 2016 Elsevier Ltd. All rights reserved.

\section{Introduction}

Evidence for abrupt and short climate changes prevailing during the late Quaternary are widespread in both marine and terrestrial archives (Bond et al., 1993; Dansgaard et al., 1993; Wang et al., 2001). These records have notably revealed a complex climate system, including close relationships between the two

\footnotetext{
* Corresponding author.

E-mail address: aurelien_royer@hotmail.com (A. Royer).
}

hemispheres (e.g. Charles et al., 1996; Blunier and Brook, 2001) as well as between high and low latitudes (e.g. Peterson et al., 2000; Haug et al., 2001; Lea et al., 2003; Schmidt et al., 2004, 2012; Deplazes et al., 2013). For tropical regions, past climate conditions were strongly influenced by the position and migration of the InterTropical Convergence Zone (ITCZ), which is linked to modifications of the Atlantic Meridional Overturning Circulation (AMOC), sea-ice expansion in the North Atlantic and pole-to-equator gradient of sea surface temperatures (e.g. Broccoli et al., 2006; Stouffer et al., 2006). Consequently, climate variability deduced from the late Quaternary archive of the Caribbean Basin has been considered as 
related to meridional displacements of the mean ITCZ position (e.g. Peterson and Haug, 2006; Hodell et al., 2008) (Fig. 1). In fact, the current climate mode of the Caribbean region is strongly influenced by seasonal changes in the displacement of the ITCZ as well as by the Bermuda-Azores high-pressure systems located in the North Atlantic that either maintain or reduce zonal trade winds. The present-day climate of this area is characterized by an annual cycle of rainfall exhibiting a bimodal structure with two rainfall maxima running from May to November, when the ITCZ shifts north of the equator, separated by a mid-summer drought in July-August (Giannini et al., 2000). However, each region of the Caribbean Basin is characterized by a distinct climate mode (Gamble et al., 2008). For example, southern areas are influenced by the Caribbean LowLevel Jet (Gamble and Curtis, 2008), while the Eastern Caribbean area is mostly influenced by the synoptic variability of the thermohaline circulation, as well as the Bermuda-Azores high-pressure systems and the North Atlantic Oscillation (NAO) (Giannini et al., 2001; Gamble and Curtis, 2008; Gamble et al., 2008).

Any attempt to investigate climate variability and its impact on both flora and fauna assemblages in the terrestrial domains of the Caribbean Islands remains challenging mainly due to the scarcity of Late Quaternary sedimentary records. Thus far, terrestrial climate records are primarily recovered from lacustrine and cave deposits. Lacustrine deposits allow for the analysis of sedimentary structures and textures (Street-Perrott et al., 1993; Bertran et al., 2004), the determination of pollen (Leyden, 1995; Bush et al., 2009; Lane et al., 2009) and ostracod assemblages (Hodell et al., 1991; Curtis and
Hodell, 1993; Holmes, 1998), as well as the stable isotope analysis of aquatic invertebrates and sedimentary organic matter (Beets et al., 2006; Malaizé et al., 2011; Yanes and Romanek, 2013). However, most shallow lakes in Central America and the Caribbean were dry during the last glacial period as tropical lakes are highly sensitive to changes in the balance between precipitation and evaporation. Nevertheless, sedimentary deposits in cave contexts can preserve speleothems (e.g. Lachniet et al., 2004; Fensterer et al., 2013; Gázquez et al., 2013; Lachniet et al., 2013) and fossil bones (e.g. Pregill et al., 1994; Lenoble et al., 2009; Bochaton et al., 2015; Stoetzel et al., 2016) as well as fossil bat guano, which may constitute climate archives over periods exceeding several thousand years (Des Marais et al., 1980; Mizutani et al., 1992a,b; Wurster et al., 2008). Indeed, continuous accumulations of laminated bat guano, which can extend from recent periods to beyond the Last Glacial Maximum (McFarlane et al., 2002; Bird et al., 2007; Wurster et al., 2008, 2010a; Onac et al., 2014, 2015; Forray et al., 2015; Widga and Colburn, 2015; Choa et al., 2016; Cleary et al., 2016), provide a high temporal resolution record of environmental changes (Wurster et al., 2007).

The purpose of this study is to evaluate the impact of past climatic changes on tropical eastern Caribbean environments, especially high-frequency fluctuations in precipitation that can be estimated from both carbon and nitrogen isotope compositions of fossil bat guano sampled from Blanchard Cave, Marie-Galante Island. The high temporal resolution of past environmental changes observed due to laminated structure of the guano is compared with

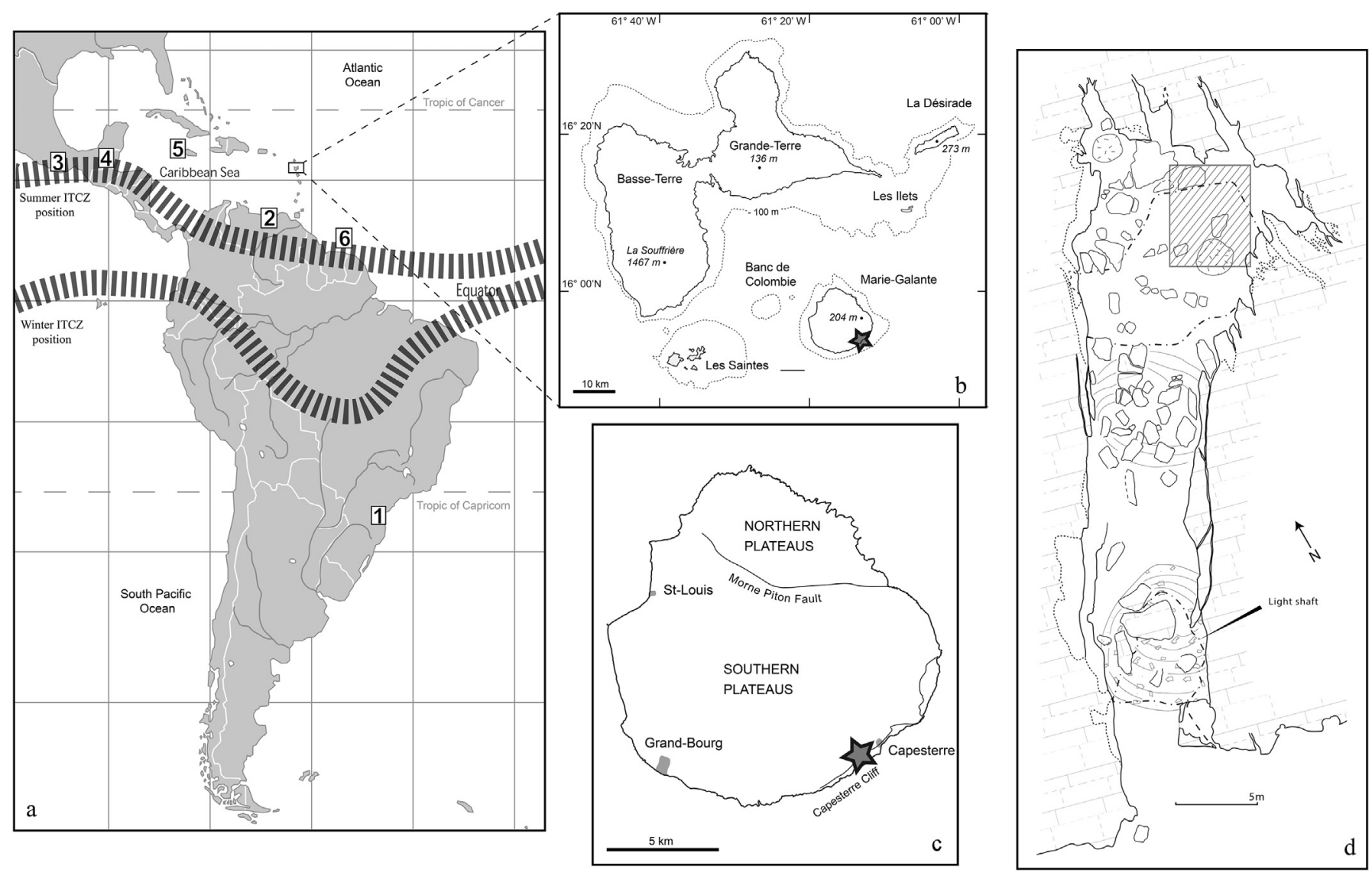

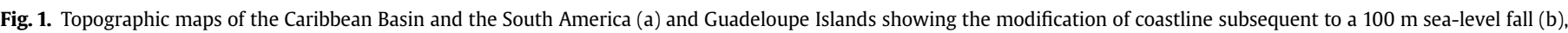

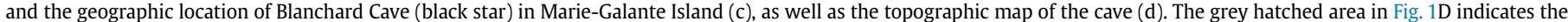

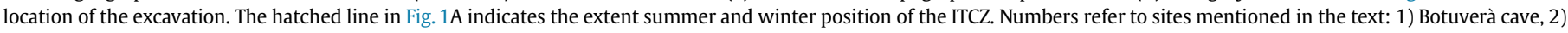
Cariaco Basin, 3) Juxtlahuaca Cave, 4) Lake Petén Itzá, 5) Lake Wallywash Great Pond, and 6) MD03-2616. 
others proxies (Cariaco Basin, Petén Itzá, polar ice cores from Greenland and Antarctica) to discuss potential teleconnections between tropical and polar regions.

\section{The Blanchard Cave: location and stratigraphy}

Marie-Galante is a carbonate flat island (maximal elevation of $204 \mathrm{~m}$ ) belonging to the Guadeloupe archipelago. This small island is located on a separate bank isolated from Guadeloupe, even during glacial lowstands. The archipelago experiences a tropical climate where rainy (June-November) and dry (December-May) seasons alternate with slight variations in temperature (mean annual temperature of $27^{\circ} \mathrm{C}$ ). Due to the low relief of the island, Marie-Galante receives limited precipitation (maximal annual rain fall of around $1500 \mathrm{~mm}$ ). The present-day environmental conditions on Marie-Galante result from a profound alteration of the landscape by historical crops such as tobacco, coffee, cotton, sugar cane and indigo (Rousteau et al., 1996). The eastern coast of the island is arid, hosting dry scrub forests and deciduous dry forests further inland whereas swamps are mainly present along the northwestern coast. The middle part of the island is characterized by ravines that host a slightly moister vegetation than the surroundings (Lasserre, 1961; Portecop, 1982; Rousteau et al., 1996).

Blanchard Cave is a flank margin cave currently located $200 \mathrm{~m}$ from the southern coastline of Marie-Galante Island, near the village of Capesterre $\left(15^{\circ} 52^{\prime} 56^{\prime \prime} \mathrm{N} ; 61^{\circ} 14^{\prime} 01^{\prime \prime} \mathrm{O}\right.$ ) (Lenoble et al., 2009). Its distance from the shore slightly varied in the past (Fig. 1b). The cave morphology is constituted of a corridor around $35 \mathrm{~m}$ length, 5-8 $\mathrm{m}$ wide and 6-7 $\mathrm{m}$ high that opens at the base of a fossil cliff $200 \mathrm{~m}$ from the sea (Fig. 1). The cave was dug into PlioPleistocene neritic limestones (Bouysse et al., 1993) and was further shaped during the high sea-level stand of the last Interglacial MIS 5 (125 ka) (Lenoble et al., 2009).

The large openness of the cave ( $5 \mathrm{~m}$ wide) makes it clearly identifiable in the landscape and explains why it has been referred to various names over time: Grotte Madame Lionel (Lasserre, 1961), Grotte Caraïbe (Barbotin, 1987), Voûte à Quinquins (Rodet, 1987), and Grotte Toto (Stouvenot, 2003). In 2005, a survey work performed at the cave entrance revealed an archaeological layer dated to the Pre-Columbian period (Stouvenot, 2005; Grouard et al., 2013). In 2008, a $2 \mathrm{~m}$ deep test pit was dug in the far end of the cave with palaeontological excavations in 2013 and 2014. This test documents, under a thin layer of modern bat guano (thickness $<0.1 \mathrm{~m}$ ), an important stratigraphy divided into twelve fossil-bearing layers overlying the bedrock (Fig. 2), which deliver faunal fossil remains (Bailon et al., 2015; Gala and Lenoble, 2015; Stoetzel et al., 2016). These twelve levels can be classified into five sedimentary facies:

- Level 1 is made of massive beige silts slightly cemented forming the uppermost part of the cave infilling.

- Level 2 is constituted of massive brown silts containing more or less residual organic matter.

- Levels 3, 5, 8, 10 and 12 are composed of brown silt-size organicrich brown sediments derived from vegetal remains defecated primarily by fruit bats. These levels are characterized by laminated deposits themselves intercalated with authigenic phosphate minerals. The observation of thin sections under a microscope revealed that these silts were formed by the accumulation of laminated and partially altered organic debris despite the occasional presence of vegetal material (Fig. $3 \mathrm{~b}$ and c).

- Levels 6, 7, 9 and 11 are formed of silts similar to those occurring in the previous facies but characterized by a massive structure including limestones debris. Under the microscope, samples from these levels exhibit numerous bioturbation patterns measuring of several centimeters in diameter generated by burrowing organisms attesting to the reworking of these deposits (Fig. 3a). Due to these bioturbation patterns, we have chosen to collect in each level samples that average $5 \mathrm{~cm}$ thickness of level deposit.

- Level 4 is constituted of a pile of blocks with voids filled by micro-laminated carbonated sands that most likely result from a single roof collapse event.

Mineralogical and chemical characterizations of the deposit (organic matter, sulfur, and carbonate content, $\mathrm{pH}$ ) indicate that these sedimentary changes do not correlate with major variations in sediment composition throughout the sequence, apart from level 4 functioning as a carbonate buffer due to its limestone debris content (cf. Suppl. material S1).

Hygric measurements have demonstrated that Blanchard Cave is a dry cave throughout the year, with frequent air circulation caused by a decrease in outside temperatures, leading to the arrival of cold air in the cave and an interruption in the thermal stratification of the ambient air (Lenoble et al., 2015). Due to these microclimate parameters, Blanchard Cave is considered as a cool chamber following the classification of bat roosting sites in the Caribbean (e.g. Rodríguez-Durán, 2010). Currently and all the year round, the cave entrance is home of a couple of harems, each composed of a dozen Jamaican fruit-eating bats (Artibeus jamaicensis), a frugivorous species belonging to the Phyllostomidae family. The far end of the cave, which hosts a colony of Antillean fruit-eating bats (Brachyphylla cavernarum), mainly functions as a nursery roost occupied seasonally. Fossil remains of the Antillean fruit-eating bat have been retrieved throughout the deposit, associated with remains of three others frugivorous or nectarivorous species found in less extent (Stoetzel et al., 2016).

No insect remains have thus far been recovered from any part of the sequence, despite a careful examination under binocular of several samples throughout the infilling. That is somewhat surprising for two reasons. First, the Antillean fruit bat has a less restrictive diet compared to other frugivorous species, enabling them to consume higher proportions of insects in some circumstances (Bond and Seaman, 1958; Soto-Centeno et al., 2001; Lenoble et al., 2014). Second, bones referable to eight insectivore species are found associated with Antillean fruit bat through the whole sequence. Such observation does not exclude, however, a contribution of insect accumulation to the deposit formation despite the well-preserved organic matter.

\section{Methods}

\subsection{Sampling method}

Guano samples were directly collected from throughout the stratigraphic sequence. Levels 3 to 11 were sampled in the northern part of the sequence (square H33 - Fig. 2), whereas level 12 was sampled in the southern part (square H31), where this particular level is more clearly identifiable. The depth of the level 12 top was corrected to correspond to the base of the level 11. Samples from levels $3,5,8,10$ and 12 comprise $2-4 \mathrm{~mm}$ of sediment continuously collected according to sedimentary levels inclination and lamination. As levels 6, 7, 9 and 11 are massive deposits, bulk samples were defined at the scale from 2 to $5 \mathrm{~cm}$ and they have been considered as mean points averaging isotopic signatures of the levels, in which they come from. In addition, a sample of modern guano collected in 2012 was analyzed in order to have a present-day reference for both $\delta^{13} \mathrm{C}$ and $\delta^{15} \mathrm{~N}$ values. 
A

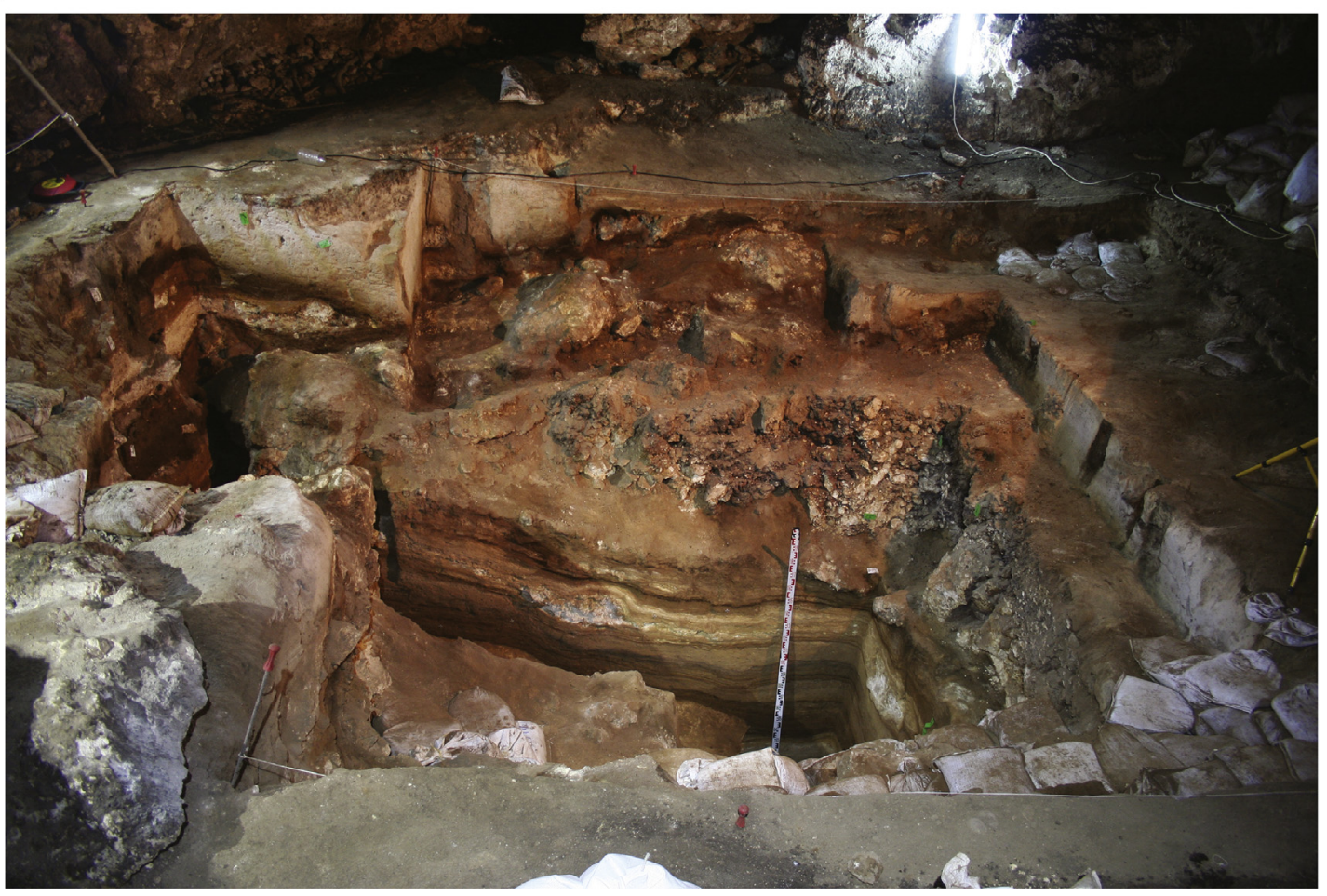

B

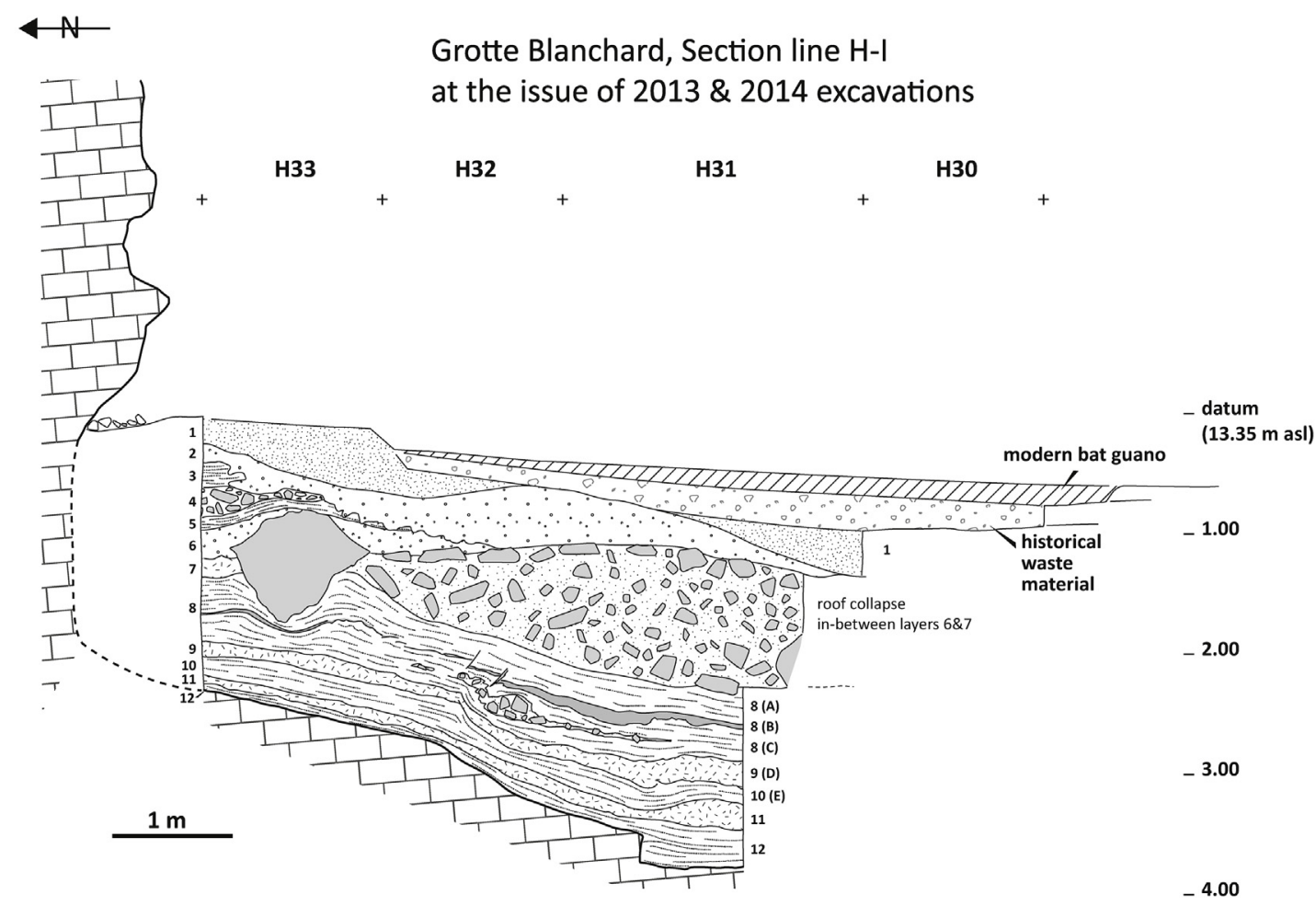

Fig. 2. Sedimentary deposits of the Blanchard Cave, (A) photography, (B) schematic representation.

\subsection{Radiocarbon dates and age modeling}

Sixteen samples of fossil guano were sent for AMS ${ }^{14} \mathrm{C}$ dates by the three institutes: Vienna Institute for Isotopes and Nuclear
Physics, Austria, which operated $\mathrm{MeOH}$ washing and acid-base-acid protocol; the laboratory of Groenigen, Netherlands, and the Artemis AMS laboratory in Saclay, France (Table 1), which have just pretreated samples with $\mathrm{HCl}$ acid to avoid any alteration of organic 


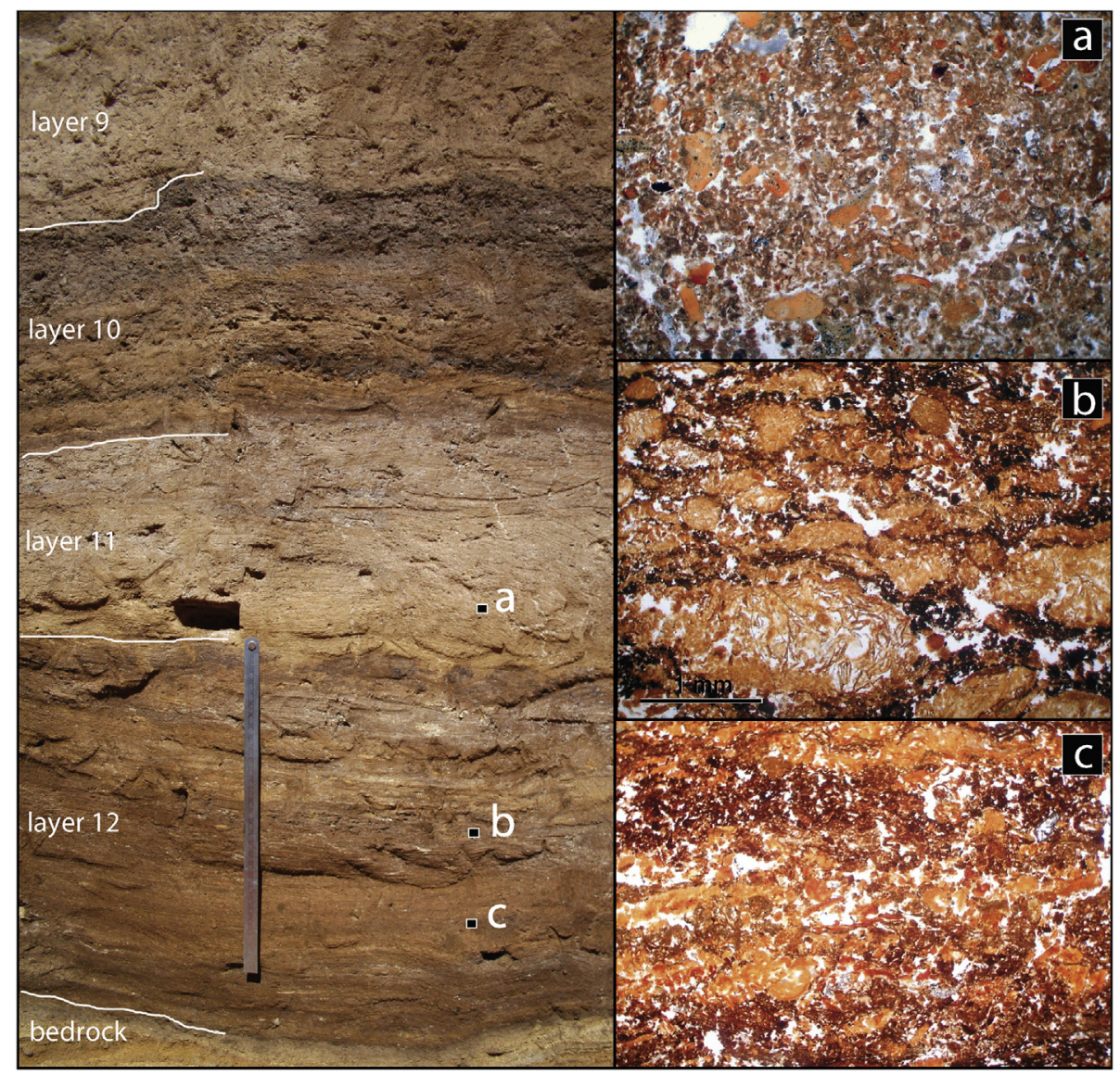

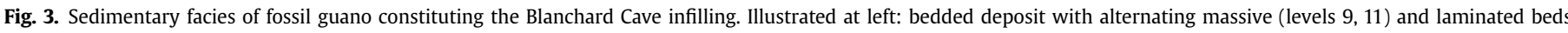

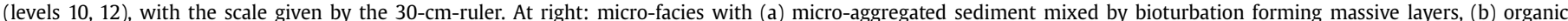

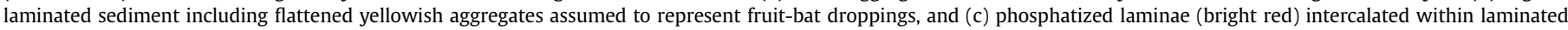

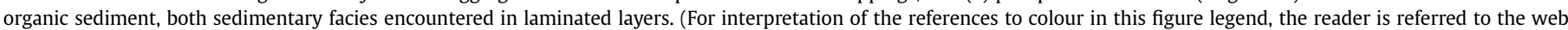
version of this article.)

Table 1

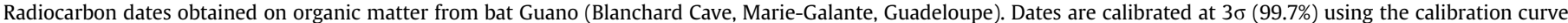
IntCal13 (Reimer et al., 2013). Depth ( $\mathrm{mm}$ ) is expressed in function of the datum level.

\begin{tabular}{|c|c|c|c|c|c|c|c|c|}
\hline & \multicolumn{4}{|c|}{$\delta^{13} \mathrm{C}$ values } & \multicolumn{4}{|c|}{$\delta^{15} \mathrm{~N}$ values } \\
\hline & $\mathrm{n}$ & Mean & Minimum & Maximum & $\mathrm{n}$ & Mean & Minimum & Maximum \\
\hline Modern Guano & 1 & -27.0 & - & - & 1 & 11.1 & - & - \\
\hline Level 3 & 23 & -25.1 & -25.6 & -24.6 & 23 & 17.4 & 14.9 & 19.0 \\
\hline Level 4 & 1 & -24.7 & - & - & 1 & 15.1 & - & - \\
\hline Level 5 & 26 & -22.0 & -25.5 & -20.4 & 26 & 21.1 & 16.4 & 22.2 \\
\hline Level 6 & 2 & -20.3 & -20.4 & -20.2 & 2 & 22.3 & 22.0 & 22.7 \\
\hline Level 7 & 3 & -22.8 & -23.3 & -21.9 & 3 & 14.2 & 12.1 & 17.4 \\
\hline Level 8 & 93 & -24.0 & -24.9 & -22.2 & 93 & 14.0 & 7.7 & 18.7 \\
\hline Level 9 & 1 & -22.5 & - & - & 1 & 11.7 & - & - \\
\hline Level 10 & 51 & -24.6 & -25.4 & -23.7 & 50 & 8.8 & 6.8 & 11.1 \\
\hline Level 11 & 1 & -24.7 & - & - & - & - & - & - \\
\hline Level 12 & 54 & -24.5 & -25.7 & -19.8 & 30 & 9.7 & 6.0 & 18.5 \\
\hline TOTAL fossil & 255 & -24.1 & -25.7 & -19.8 & 229 & 13.5 & 6.0 & 22.7 \\
\hline
\end{tabular}

matter with basic treatment. The reported dates were calibrated at $3 \sigma(99.7 \%)$ using the IntCal13 calibration curve (Reimer et al., 2013). Nine of these dates match individual samples (samples from Groeningen and Vienna). The seven remaining dates were obtained from Artemis before the high resolution sampling conducted for isotopic analyses to evaluate the stratigraphy. They correspond to five to ten samples, conducting thus to engender larger confidence intervals in the age model compared to the first set of dates from
Groeningen and Vienna (Table 1).

The age-depth model was generated by using in the R-CRAN software (R Development Core Team, 2008) the 'Classical age-depth modeling' (Clam software version 2.2) developed by Blaauw (2010) and by applying a linear regression to the data (Fig. 4). Dates range from the top of level 3 to the middle part of level 12 while extrapolated ages were assigned to the last twenty-five samples from level 12 . As level 4 is a roof collapse, it was considered as an 


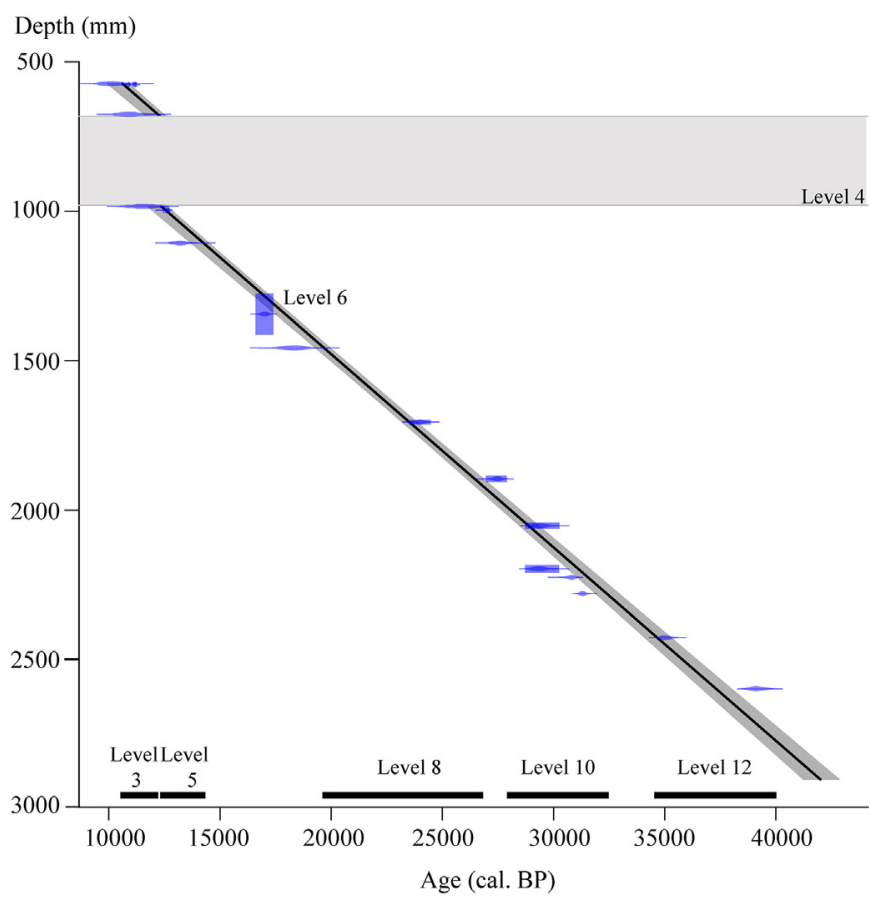

Fig. 4. Age-depth model and radiocarbon dates calibrated using Clam software v2.2 (Blaauw, 2010). The grey area defines the $99.7 \%$ confidence envelope.

instantaneous event. With the exception of level 4, the mean accumulation rate is estimated at $0.06 \mathrm{~mm} /$ year, suggesting that each sample represents $50 \pm 15$ years. Dehydration and compaction effects can explained this low rate of accumulation, as well as an irregular occupation of the cave by bats. Age uncertainties at $99.7 \%$ in this age-depth model are less than $1.8 \mathrm{ka}$.

\subsection{Stable isotope measurements}

Carbon and nitrogen isotope ratios were measured from a subset of guano samples collected, with 255 and 229 samples, respectively (Table 2; Suppl. material S2). Each sample was sieved with a $500 \mu \mathrm{m}$ mesh and decarbonated using an $8 \%$ hydrochloric acid solution for $12 \mathrm{~h}$ at $90^{\circ} \mathrm{C}$ in order to remove limestone bedrock particles before being washed with deionized water and dried at low temperature. Aliquots of guano samples from 0.5 to $2.0 \mathrm{mg}$ were loaded into tin capsules and analyzed with an isotope ratio mass spectrometer (IsoPrime GV Instruments ${ }^{\circledR}$ ) interfaced with an Elemental Analyzer (EA; Flash2000, ThermoFisher ${ }^{\circledR}$ ) at the EPOC Laboratory of the University of Bordeaux, France. Daily drift of isotopic measurements was corrected using a series of internal isotopic references (acetanilide $\mathrm{C}_{8} \mathrm{H}_{9} \mathrm{NO}$, casein $\mathrm{C}_{47} \mathrm{H}_{48} \mathrm{~N}_{3} \mathrm{NaO}_{7} \mathrm{~S}_{2}$, glycin $\mathrm{C}_{2} \mathrm{H}_{5} \mathrm{NO}_{2}$ ). Stable isotope ratios are expressed in the conventional delta notation as parts per thousand (\%o) deviations from the Vienna Pee Dee Belemnite (V-PDB) international standards for $\delta^{13} \mathrm{C}$ and atmospheric $\mathrm{N}_{2}$ for $\delta^{15} \mathrm{~N}$. Analysis uncertainty was better than $0.3 \%$ for $\delta^{15} \mathrm{~N}$ and $0.2 \%$ for $\delta^{13} \mathrm{C}$. Duplicate measurements were performed for 81 samples.

\subsection{Interpretation of carbon and nitrogen isotope compositions of bat guano}

Carbon and nitrogen isotope compositions of fossil animalderived organic remains, such as bones, dung and guano, are commonly used to reconstruct palaeoenvironments. The underlying basis of stable isotope investigations on animal organic remains is that 1) there are isotopic relationships within the biosphere and geosphere due to fractionation taking place during natural chemical and physical processes. This results in isotopic differences between different foods consumed; and 2) climatic parameters can affect fractionation during these processes, thus modifying the isotopic signatures of the diet. These isotopic signatures are recorded during the absorption and incorporation of food in both the consumer tissues (e.g. De Niro and Epstein, 1981; Kelly, 2000) and feces (Herrera et al., 2001a, 2001b; Painter et al., 2009; SotoCenteno et al., 2014). Thus, changes in climate are recorded in the isotopic signatures of animal body tissues and feces.

The primary control on plant $\delta^{15} \mathrm{~N}$ values is their ability to use nitrogen, which is absorbed directly from the atmosphere through symbiotic soil bacteria for leguminous plants or from soil nitrate for non-leguminous plants. At the global scale, $\delta^{15} \mathrm{~N}$ values of soils and plants decrease with the reduction of mean annual temperature and the increase of mean annual precipitation (Amundson et al., 2003), both being climatic factors that ultimately control the biological activity and the soil nitrogen cycling. This assumption led many scientists to use $\delta^{15} \mathrm{~N}$ variation of fossil animal organic remains as a proxy of the amount of precipitation. However, it is important to note that plant $\delta^{15} \mathrm{~N}$ values can vary seasonally up to several per mil, and also depend on plant segments (Kolb and Evans, 2002), and between various plant taxa occurring in the same site (Handley et al., 1999). Such complexity, related to the

Table 2

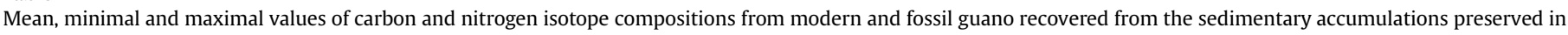
Blanchard Cave, Marie-Galante, Guadeloupe.

\begin{tabular}{|c|c|c|c|c|c|c|c|}
\hline Laboratory & Ref-labo & Unit & Depth (mm) & Age $14 \mathrm{C}$ yr BP & S. dev. $(1 \sigma)$ & IntCal09 min BP & IntCal09 max BP \\
\hline Vienna & A/GB-13-13 & 3 & $573 \pm 1.25$ & 8999 & 313 & 9014 & 11404 \\
\hline Artemis & Lyon-5726 (SacA-14261) & 3 & $576.25 \pm 10$ & 9740 & 50 & 10789 & 11270 \\
\hline Vienna & A/GB-13-59 & 3 & $676 \pm 1.25$ & 9291 & 351 & 9400 & 12238 \\
\hline Vienna & A/GB-13-63 & 5 & $984 \pm 1.5$ & 10005 & 335 & 10249 & 12805 \\
\hline Artemis & Lyon-6976 (SacA 19445) & 5 & $997 \pm 16.5$ & 10690 & 70 & 12421 & 12750 \\
\hline Vienna & A/GB-13-113 & 5 & $1106.5 \pm 1.5$ & 11348 & 285 & 12429 & 14195 \\
\hline Artemis & Lyon-6977 (SacA 19446) & 6 & $1344 \pm 137$ & 14010 & 80 & 16546 & 17452 \\
\hline Vienna & A/GB-13-117 & 8 & $1457 \pm 1$ & 15081 & 447 & 16786 & 19958 \\
\hline Artemis & Lyon-6978 (SacA 19447) & 8 & $1704.75 \pm 16.25$ & 19940 & 150 & 23427 & 24530 \\
\hline Artemis & Lyon-6979 (SacA 19448) & 8 base & $1894.5 \pm 20.75$ & 23200 & 220 & 26764 & 27960 \\
\hline Artemis & Lyon-8497 (SacA 26110) & 10 & $2052 \pm 20$ & 25320 & 220 & 28663 & 30400 \\
\hline Artemis & Lyon-8498 (SacA 26111) & 10 & $2196 \pm 24$ & 25300 & 220 & 28649 & 30374 \\
\hline Vienna & A/GB-13-387 & 10 & $2220 \pm 1.25$ & 26539 & 196 & 30154 & 31227 \\
\hline Artemis/Groeningen & Lyon-11133(Gra) /GB-14-409 & 10 & $2279.25 \pm 2$ & 27510 & 140 & 30988 & 31717 \\
\hline Artemis/Groeningen & Lyon-11134(Gra)/GB-14-445 & 12 & $2426 \pm 1$ & 31150 & 180 & 34517 & 35698 \\
\hline Artemis/Groeningen & Lyon-11135(Gra)/GB-14-499 & 12 & $2596.5 \pm 1.5$ & 34640 & 230 & 38440 & 40004 \\
\hline
\end{tabular}


simultaneous participation of processes of isotope fractionation operating within the nitrogen cycle, generally produces weak statistical relationships between plant $\delta^{15} \mathrm{~N}$ values and considered climate factors (Amundson et al., 2003; Murphy and Bowman, 2006, 2009; Makarov, 2009).

Carbon isotope compositions of plants mainly depend on metabolic pathways for assimilating atmospheric carbon (i.e. plants C3, C4 and CAM), which is more or less modulated by local environmental parameters such as water stress, $\mathrm{CO}_{2}$ partial pressure, exposure to sunlight and openness of the vegetation. Changing vegetation patterns in bat foraging areas (from 5 to $20 \mathrm{~km}$ ) are recorded in both carbon and nitrogen isotope compositions of insectivorous bats (Wurster et al., 2007) and phytophageous (Royer et al., 2015) bat feces. The digesta of insectivorous and phytophageous bats is quickly transited in a few hours or less without undergoing radical changes in the gastrointestinal tract (Morrison, 1980; Painter et al., 2009). The isotopic carbon difference between bat diet and their feces was estimated by Salvarina et al. (2013) to be $-0.11 \pm 0.8 \%$ and by Des Marais et al. (1980) as close to $0.8 \%$, respectively. Consequently, in the case of phytophageous bats, it can be assumed that this isotopic fractionation is close to zero and that stable isotope compositions of their feces directly reflect those of the plants consumed. Past climatic and environmental changes can influence isotopic compositions of feces as bats modify their diet to changes in the diversity and abundance of local resources, including the ratio between $\mathrm{C} 4$ and C3 plants.

Distinct strategies of carbon fixation among plants allowed the determination of a range of $\delta^{13} \mathrm{C}$ values comprised between -36 and $-22 \%$ for $\mathrm{C} 3$ while $\mathrm{C} 4$ are less ${ }^{13} \mathrm{C}$-depleted relative to their $\mathrm{CO}_{2}$ source with values ranging from -15 to $-10 \%$ (Bender, 1971 ; Smith and Epstein, 1971). Internal variations in $\delta^{13} \mathrm{C}$ values for photosynthetic plants result from local conditions including ambient light conditions, temperature, $p \mathrm{CO}_{2}$ and water availability (e.g. Smith et al., 1976; Farquhar et al., 1989; Ehleringer et al., 1997; Kohn, 2010). For example, subcanopy C3 plants, which grow in humid and shaded environments, have lower $\delta^{13} \mathrm{C}$ values than those growing in arid and open environments. Studies have shown that part of the $\delta^{13} \mathrm{C}$ variability of $\mathrm{C} 3$ plants is influenced by local precipitation, and significant correlations have been demonstrated between the average $\delta^{13} \mathrm{C}$ values of local C3 plants and mean annual precipitations (Diefendorf et al., 2010; Kohn, 2010). Through differences in photosynthetic pathway and plant physiology, climate conditions act as a primary control on large-scale variation in $\delta^{13} \mathrm{C}$ values of vegetation and on the distribution and abundance of $\mathrm{C} 3$ and C4 plants (Teeri and Stowe, 1976; Tieszen et al., 1997). Consequently, stable carbon isotope compositions of fossil guano reflect the stable isotope composition of plants, which are in turn related to local environmental conditions.

Furthermore, it is important to note that the mode of plantclimate interactions change over time, notably influenced by variations in atmospheric $\mathrm{CO}_{2}$ concentration and ${ }^{13} \mathrm{C} /{ }^{12} \mathrm{C}$ ratios, i.e. Suess effect $\left(\delta^{13} C_{a t m}\right)$ (Arens et al., 2000; Prentice and Harrison, 2009). These modifications can produce important changes in plant $\delta^{13} \mathrm{C}$ values, meaning that $\delta^{13} \mathrm{C}$ values of past vegetation must be corrected from these parameters in order to quantify past environmental changes. A negative relationship between $\mathrm{CO}_{2}$ concentrations and $\delta^{13} \mathrm{C}$ values in plants has been documented by several authors (Van de Water et al., 1994; Feng and Epstein, 1995; Hatté et al., 2009). Indeed, $\mathrm{CO}_{2}$ concentrations from the preindustrial period were lower than today, decreasing down to 200 ppm or less during the Last Glacial period (Barnola et al., 1987; Ahn and Brook, 2008). In addition, changes in $\delta^{13} \mathrm{C}_{\mathrm{atm}}$ have been shown to have a more direct effect than $\mathrm{CO}_{2}$ concentration on plant $\delta^{13} \mathrm{C}$ values (Farquhar et al., 1989; Feng and Epstein, 1995; Arens et al., 2000). The current $\delta^{13} \mathrm{C}_{\mathrm{atm}}$ value is close to $-8.0 \%$ whereas the pre-industrial period was marked by $\delta^{13} \mathrm{C}_{\mathrm{atm}}$ estimated to be about -6.5\% (Leuenberger et al., 1992; Keeling et al., 2005).

Consequently, $\delta^{13} \mathrm{C}$ values of plants recorded in fossil guano must be corrected to take into account their development during periods with both different $\mathrm{CO}_{2}$ concentrations and $\delta^{13} \mathrm{C}_{\mathrm{atm}}$. Firstly, we used $\mathrm{CO}_{2}$ concentration values proposed by Ahn and Brook (2008) and we used a coefficient of $-2.0 \pm 0.1 \%$ per $100 \mathrm{ppm}$ between $\mathrm{CO}_{2}$ concentrations and plant $\delta^{13} \mathrm{C}$ values, leading to obtain a maximal $\delta^{13} \mathrm{C}$ correction of $+1.6 \%$ for the lowest $\mathrm{CO}_{2}$ concentration of the Last Glacial Maximum. Secondly, we used data from Schmitt et al. (2012) who estimated $\delta^{13} \mathrm{C}_{\mathrm{atm}}$ variations ranging from $-6.7 \pm 0.06$ to $-6.3 \pm 0.03 \%$ o during the period spanning from 24 to $6 \mathrm{ka} \mathrm{BP}$, with small variations ranging from 6.46 to 6.40 between 24.0 and $17.4 \mathrm{ka}$ BP. Beyond $24.0 \mathrm{ka}$ BP, the value used was $-6.4 \%$. These two corrections have been calculated on the basis of the first sample (P13 - Suppl. material S2), which is characterized by a $\delta^{13} \mathrm{C}_{\mathrm{atm}}$ value of $-6.6 \%$ and a $\mathrm{CO}_{2}$ concentration of 265.4 ppm.

\section{Results}

Guano from modern Antillean fruit-eating bats collected from Blanchard Cave has a $\delta^{13} \mathrm{C}$ value of $-27.0 \%$ in contrast to those of fossil bat guano that range from -25.7 to $-19.8 \%$ throughout the stratigraphic sequence (Table 2; Suppl. material S2; Fig. 5). These $\delta^{13} \mathrm{C}$ values reflect a diet mainly based on C3 plants, which are associated for the highest values superior to $-22 \%$, at least, with a contribution of $\mathrm{C} 4$ plants. Intra-level variations, which can be significant as in levels 5 and 12 with amplitudes in $\delta^{13} \mathrm{C}$ variations reaching up to 5.1 and $5.9 \%$, respectively, are more important than the inter-level variations that do not exceed $3.1 \%$ (see levels $3,5,8$, 10 and 12). Consequently, no correlation is evident between the various levels and climatic events, and then there is no reason to use the stratigraphic delimitations to fragment the isotopic signals, except to differentiate levels laminated from those non-laminated. The highest $\delta^{13} \mathrm{C}$ values were observed in level 5 dated to the Bølling-Allerød interstadial and at the beginning of level 12 dated to around $34.7 \mathrm{ka} \mathrm{BP}$, while the lowest $\delta^{13} \mathrm{C}$ values were measured in the uppermost samples of the sequence associated with Younger-Dryas and the beginning of the Holocene. The $\delta^{13} \mathrm{C}$ values corrected for $\mathrm{CO}_{2}$ concentration and atmospheric $\delta^{13} \mathrm{C}$ range from -25.7 to $-18.8 \%$ (Fig. 5, dashed line). These corrections do not strongly modify either the trends of $\delta^{13} \mathrm{C}$ variations nor their intra-level magnitudes but shift the lower samples (dated to before the Lateglacial period) towards higher $\delta^{13} \mathrm{C}$ values with a maximum offset of $1.6 \%$ in samples dated from Last Glacial Maximum, reinforcing contrasts between the isotopic compositions of present-day and past guano.

Modern guano from Antillean fruit-eating bats has a $\delta^{15} \mathrm{~N}$ value of $11.1 \%$. Nitrogen isotope compositions of fossil bat guano range from 5.9 to $22.7 \%$ o throughout the stratigraphic sequence, with a mean value of $13.5 \%$. Like carbon isotope compositions, the highest $\delta^{15} \mathrm{~N}$ values were observed in levels 5 and 6 that are dated to the Bølling-Allerød interstadial and Heinrich event 1, respectively. The lowest $\delta^{15} \mathrm{~N}$ values were measured in level 12 that has been dated to between 37 and $36 \mathrm{ka}$ cal. BP. Furthermore, two sizable changes in $\delta^{15} \mathrm{~N}$, greater than $11 \%$ have been observed close to 23.5 and 35.0 ka cal. BP.

For the general trends, the $\delta^{13} \mathrm{C}$ and $\delta^{15} \mathrm{~N}$ values are positively correlated throughout the sequence $(\mathrm{Rho}=0.43, \mathrm{p}<0.0001)$ except during level 8 (Rho $=0.02, p=0.80)$. It is noteworthy that several time lags were not recorded in the same way by carbon and nitrogen isotope compositions of fossil guano. For example, during the Bølling-Allerød period, $\delta^{13} \mathrm{C}$ values decreased from around 13.7 


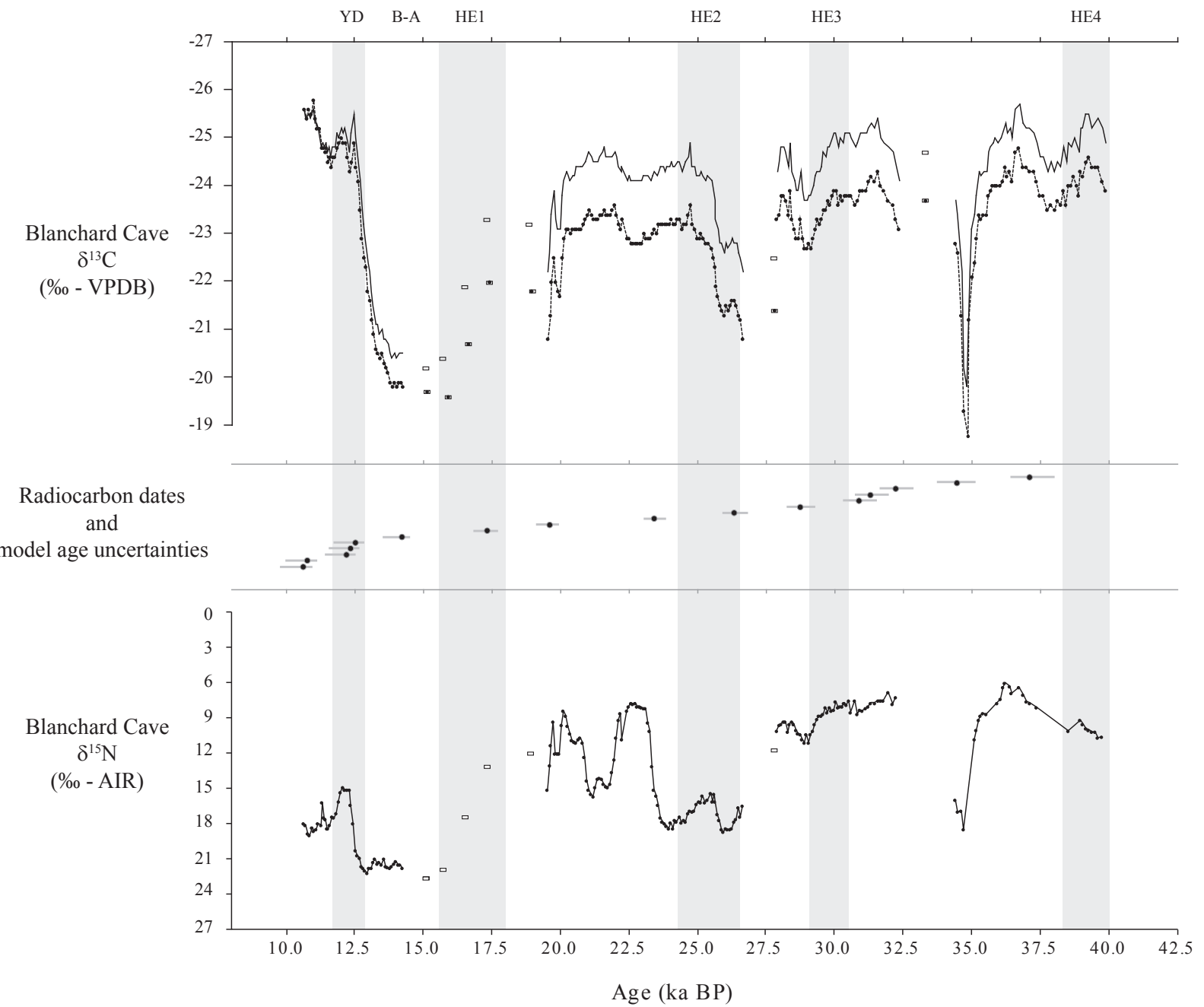

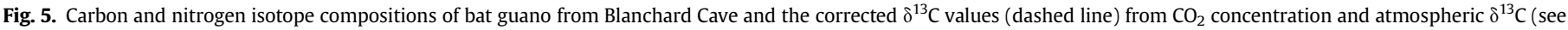
paragraph 3.4) reported along the age estimated from the age-depth model, illustrated with the age uncertainties calculated at $99.7 \%$ (Suppl. material S2).

ka cal. BP, whereas $\delta^{15} \mathrm{~N}$ began to decrease around $12.9 \mathrm{ka}$ cal. BP, at the beginning of the Younger-Dryas.

The $\mathrm{C} / \mathrm{N}$ ratios vary from 3.3 to 6.0 , which corresponds to the range of values for modern insectivorous bats (Bird et al., 2007; Emerson and Roark, 2007; Wurster et al., 2007) and close to that of modern frugivorous bats extending their diet to insects (Royer et al., 2015). These ratios measured in fossil guano from insectivorous bats are much higher than those that could be expected for altered samples because of oxidation and subsequent carbon release operating in tandem with nitrogen mineralization (Choa et al., 2016). C/N ratios are weakly, but significantly and negatively correlated with $\delta^{13} \mathrm{C}(\mathrm{Rho}=-0.197, \mathrm{p}<0.002)$ and negatively correlated with $\delta^{15} \mathrm{~N}(\mathrm{Rho}=-0.503, \mathrm{p}<0.0001)$ throughout the sequence.

\section{Discussion}

\subsection{Genesis of guano deposits and their preservation}

The fossil bat guano deposit of Blanchard Cave indicates that bats regularly occupied the cave since the last $40 \mathrm{ka}$ cal. BP, as evidenced by abundant fossil bat bones found throughout the deposit as well (Stoetzel et al., 2016). Eight bat species are currently known on Marie-Galante with four phytophageous, three insectivorous and one piscivorous bats (Masson et al., 1990; Breuil and Masson, 1991; McCarthy and Henderson, 1992). This modern fauna represents only a small part of the bat community inhabiting the Island during the Late Pleistocene, constituted at least by twelve species including four nectarivorous and frugivorous bats. No insect remains were recovered from the sequence, whereas the occurrence of degraded vegetal tissues in the sediment suggests that the Pleistocene guano in the cave mostly resulted from phytophageous bats. On the other side, consumption of insects cannot be excluded, both considering the occurrence of insectivorous bat remains in the deposit, and the $\mathrm{C} / \mathrm{N}$ ratio closer to bats including at least a part of insects in their diet compared to those having a restricted frugivorous diet (Royer et al., 2015). This part of insect consumption is difficult to quantify. Even if this issue does not compromise the data or interpretations, as $\delta^{13} \mathrm{C}$ values of both reflect plant values and therefore humidity, the main risk is to add uncertainties of one trophic level in case where bat populations are switching from one dominant guild to another one. However, the absence of sizable variations in $\mathrm{C} / \mathrm{N}$ ratios and in mineralogical contents throughout the deposit of Blanchard Cave let to suggest that no major changes have occurred in bat occupations of the cave in term of guild proportion. Consequently, stable isotope compositions of this fossil guano should mainly reflect the composition of plants consumed by these individuals. 
As noted above, the massive sedimentary structure associated with burrow imprints in levels 6, 7, 9 and 11 provide clear evidence for bioturbation of a still unclear nature, although the action of ground dweller animals, such as the burrowing owl (Athene cunicularia), which is known to have inhabited the Caribbean islands during the Pleistocene (Pregill and Olson, 1981; Pregill et al., 1994) is likely. Apart from these levels, the other deposits are characterized by well-preserved laminated sediments with no evidence for bioturbation or post-depositional reworking. Moreover, observation of thin sections did not reveal the presence of either an organic mobile fraction in the sediment or patterns of water percolation. Finally, the dry micro-climate of Blanchard Cave (Lenoble et al., 2015) has also favored the preservation of buried organic matter. All these criteria suggest that the stable isotope compositions of laminated fossil guano are likely to reliably record changes in local vegetation patterns in response to global climatic forcing.

In particular, the preservation of the original $\delta^{15} \mathrm{~N}$ signal is regularly questioned through studies dealing with fossil guano, due to potential post-depositional alteration involving volatilization of ammonia. Such alterations, even if they seem to not engender significant carbon isotope fractionation, may favor ${ }^{15} \mathrm{~N}$-enrichment by as much as 7\%o (Mizutani and Wada, 1988; Bird et al., 2007; Wurster et al., 2010b). Two patterns in $\delta^{15} \mathrm{~N}$ values are considered as suspicious: firstly, fossil guano values higher than modern ones, even if such values can result equally from other parameters such as aridity; and secondly, the chemical changes should invariably lead to strong correlations between elemental ratios and isotopic compositions (Wurster et al., 2010b). In this study, the Blanchard Cave is characterized by a large range of $\delta^{15} \mathrm{~N}$ values, with $\delta^{15} \mathrm{~N}$ values higher than modern ones by about $10 \%$, and that co-vary with $\mathrm{C} / \mathrm{N}$ ratios throughout the sequence. As a consequence, variations in $\delta{ }^{15} \mathrm{~N}$ values observed at Blanchard Cave are difficult to interpret. Indeed, feces nitrogen directly reflects the nitrogen isotope composition of the diet, therefore significant changes in bat diet could explain these changes in $\delta^{15} \mathrm{~N}$ values. A second possibility concerns the impacts of significant changes in plant communities, with modifications of leguminous plant proportions (leading to $\delta^{15} \mathrm{~N}$ values close to zero when these plants are abundant) or with changes of nitrogen sources used by plants (ammonium $\mathrm{NH}_{4}^{+}$ versus nitrate $\mathrm{NO}_{3}^{-}$). It is noticeable that during some intervals, such as the Allerød, changes in $\delta^{13} \mathrm{C}$ values preceded those observed for the $\delta^{15} \mathrm{~N}$ values by $500-2000$ years. Similar time lags between climatic changes and $\delta^{15} \mathrm{~N}$ records of fauna have equally been documented in Europe during the Late Pleistocene, probably due to the complexity of the soil-plant nitrogen cycle (e.g. Stevens et al., 2008; Stevens et al., 2014). Finally, these significant changes in $\delta^{13} \mathrm{C}$ values, which partly co-varied with $\delta^{15} \mathrm{~N}$ values considering a slight time lag, could suggest a record of similar environmental conditions changes.

As the organic matter has undergone considerable decomposition and loss through microbial reprocessing and remineralisation, it is important to assess the potential impact of post-depositional processes on the isotopic composition of guano. Although diagenetic influences cannot be completely ruled out, both the lack of significant covariation between elemental ratios and carbon isotope values and the lack of significant differences between elemental ratios and age attest a lack of significant diagenetic alteration at least for carbon.

\subsection{Environmental conditions on Marie-Galante from 40 to $10 \mathrm{ka}$} $B P$

The Blanchard Cave record indicates that environmental conditions from 40 to $10 \mathrm{ka}$ cal. BP were locally drier than today because bat guano $\delta^{13} \mathrm{C}$ values are higher than the modern ones
(Fig. 6). Meanwhile, over the period spanning from 40 to $19 \mathrm{ka}$ cal. $\mathrm{BP}$, guano $\delta^{13} \mathrm{C}$ values tend to be low, suggesting overall wetter environmental conditions compared with 16 - 13 ka cal. BP. The relatively high $\delta^{13} \mathrm{C}$ values suggest four dry events. The first one is a brief dry period of about 500 years, which peaked at $34.7 \mathrm{ka}$ cal. BP and was also characterized by an increase in $\delta^{15} \mathrm{~N}$ values. This dry event, which is one of the biggest and shortest through the Blanchard record, has no equivalent with records from other proxies (Fig. 6). A second dry event occurred from 27.8 to 26 ka cal. BP. Dry conditions returned around $19.5 \mathrm{ka}$ cal. BP and then again between Heinrich event 1 and the Bølling interstadial, with the period from 16.6 to $13.5 \mathrm{ka}$ cal. BP characterized by the lowest $\delta^{13} \mathrm{C}$ values and highest $\delta^{15} \mathrm{~N}$ values. The timing of the onset of this last drought event is, however, not accurately documented due to the bioturbated nature of levels 7 and 6 . Nevertheless, this dry period continued until at least the Allerød interstadial, when $\delta^{13} \mathrm{C}$ values began to progressively decrease. Samples from the final level 3 , which are estimated to date between the Younger-Dryas and the beginning of the Holocene based on age uncertainties in the agedepth model, recorded the lowest bat guano $\delta^{13} \mathrm{C}$ values suggesting wetter conditions without reaching those prevailing today (Fig. 6). However, it is noteworthy that Younger-Dryas could have been blurred by the roof collapse associated with level 4 . Indeed, we cannot exclude that this event may have resulted in a lag in the record in the time span between 12.6 and $11.5 \mathrm{ka}$ cal. BP following uncertainties from the model-age.

\subsection{Climatic and environmental conditions of the Caribbean area}

The Late Pleistocene of the Caribbean Basin has been considered for a long time as a uniformly dry period, mainly due to the scarcity of continental archives such as speleothems or lacustrine deposits, extending beyond the dry period of the Younger-Dryas (Goodfriend and Mitterer, 1988; Hodell et al., 1991; Leyden, 1995; HigueraGundy et al., 1999). In the Eastern Caribbean Islands, one of the rare Pleistocene sedimentary deposits comes from the 'Wallywash Great Pond' in Jamaica. The period spanning from 93.0 to $9.5 \mathrm{ka}$ BP, however, was roughly described as dominated by dry and cold conditions (Street-Perrott et al., 1993; Holmes, 1998), an interpretation fitting the common model of a succession of wet interglacial and dry glacial stages prevailing in neotropical regions.

The few currently known sedimentary continuous records that extended beyond the Late Glacial period have challenged this 'wetdry' dichotomy, notably that from the Cariaco Basin, Venezuela (Peterson et al., 2000; Haug et al., 2001; González et al., 2008; Deplazes et al., 2013) and the Lake Petén Itzá, Guatemala (Hodell et al., 2008; Pérez et al., 2011; Escobar et al., 2012). These two sedimentary archives have shown, as observed under high latitude regions, the presence of a considerable tropical climate variability in the Caribbean Basin, as now equally observed in the Blanchard Cave sequence. The development of humid or dry climatic conditions has been interpreted as resulting from modifications of the mean position of the ITCZ (Fig. 6). In particular, studies of the Petén Itzá deposits revealed that the western Caribbean area witnessed cooler climate conditions $\left(\geq 2.5{ }^{\circ} \mathrm{C}\right)$ during the Last Glacial Maximum (23-18 ka BP) compared to current conditions (Hodell et al., 2008), decreasing during Heinrich Stadial by up $6-10{ }^{\circ} \mathrm{C}$ relative to today (Grauel et al., 2016). In addition, the Last Glacial Maximum was more humid than the one spanning from $\sim 19$ to 15 ka BP (Heinrich event 1) (Fig. 6), which is considered to have experienced the most arid conditions based on ostracod oxygen stable isotope compositions (Escobar et al., 2012). Stable isotope compositions of bat guano accumulated in the Blanchard Cave generally reflect overall drier environmental conditions during the Late Pleistocene compared to modern ones, supporting the 


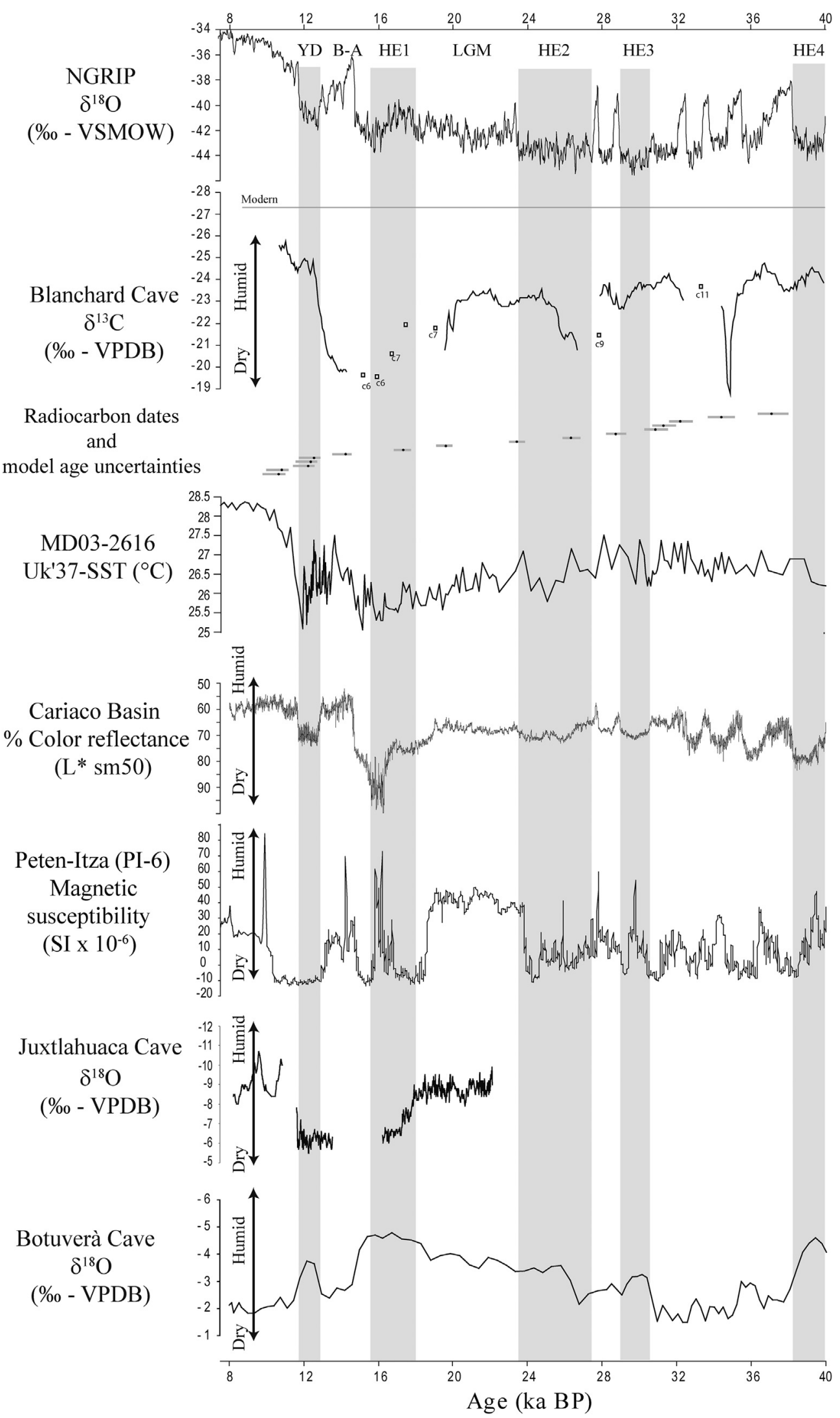

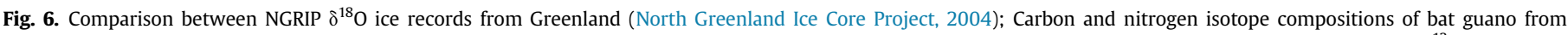

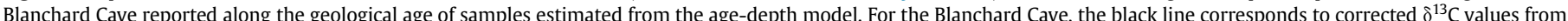

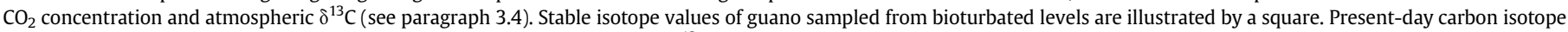

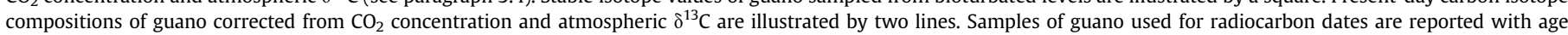

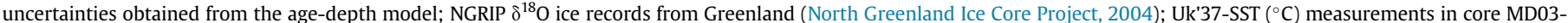

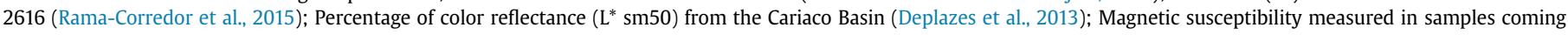

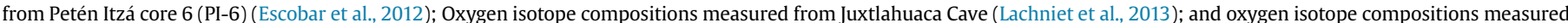

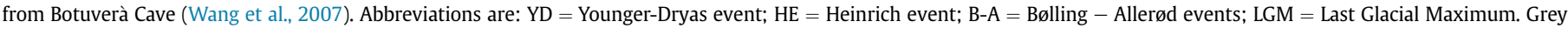
intervals indicate the four Heinrich and the Younger Dryas events. 
hypothesis of arid conditions connected to the strengthening of trade winds. Moreover, stable isotope compositions of guano from the Blanchard Cave, the first terrestrial sequence documenting Marine Isotopic Stages 3 and 2 in the Lesser Antilles, suggest that the Last Glacial Maximum period in this area was characterized by relative humid conditions in comparison to Heinrich event 1 (Fig. 6). Similar patterns have been observed at Petén Itzá and in stalagmites in southwestern Mexico from Juxtlahuaca Cave (Lachniet et al., 2013), which present low $\delta^{18} \mathrm{O}$ values of calcite during the Last Glacial Maximum period. Climate proxies from South America present an inverse pattern due to ITCZ migration, as illustrated by speleothems from Botuverà Cave in Brazil that show a drier LGM compared to the Heinrich event 1 (Wang et al., 2007).

However, the environmental variations observed at Blanchard Cave do not perfectly match patterns recognized in the Cariaco Basin or at Petén Itzá and Botuverà Cave (Brazil). In particular, an opposite trend seems to be identified for the Younger-Dryas and to a lesser extent for Heinrich event 2. In fact, the pollen signal from Petén Itzá indicates that the period of maximum aridity spanned from 18 to $11 \mathrm{ka}$ BP (including Heinrich event 1 and the YoungerDryas), despite sufficiently wet conditions during the YoungerDryas that could support a forest cover with a gradual change toward more mesic conditions from 13 to $11 \mathrm{ka} \mathrm{BP} \mathrm{(Bush} \mathrm{et} \mathrm{al.,} \mathrm{2009).}$ The Juxtlahuaca Cave stalagmites present a similar climatic record with high $\delta^{18} \mathrm{O}$ values recorded throughout Heinrich event 1 to the end of the Younger-Dryas (Lachniet et al., 2013), again suggesting this period was especially dry. Such discrepancies is relatively surprising. Thus, they questioned the reliability of ITCZ model in this area that can be in reality more complex than previously known, for example by experiencing a regionalization of climate in response to interrelated atmospheric conditions, as already evidenced during the mid-Holocene in northern Caribbean (e.g.

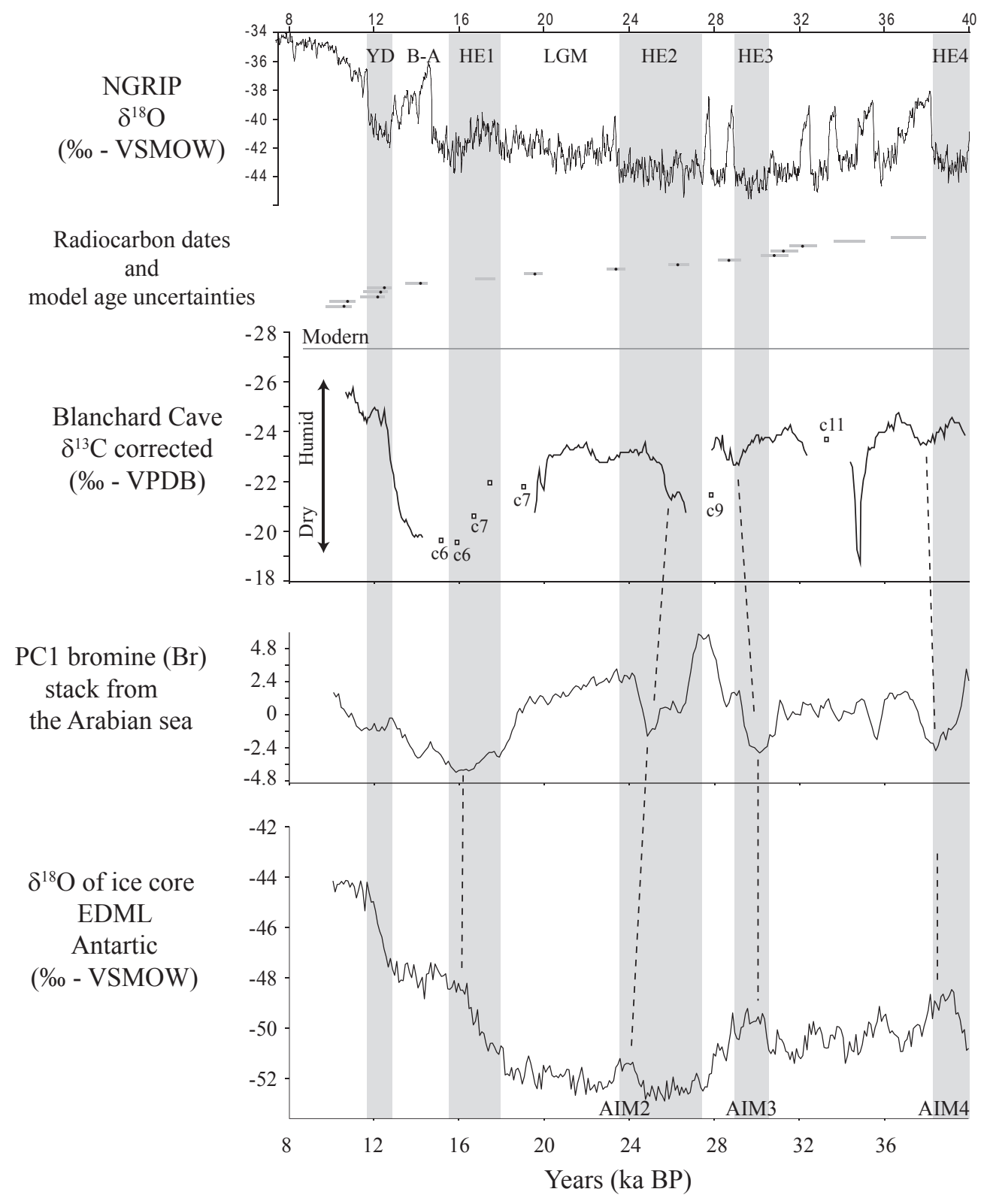

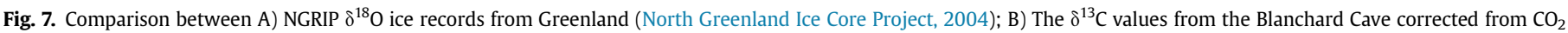

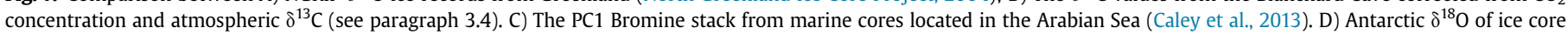
$\mathrm{EDML}$ Dome C. AIM = Antarctic Isotope Maximum. 
Malaizé et al., 2011). To investigate such issues, complementary records are, however, necessary. On the other side, these discrepancies questioned also the effects of uncertainties in each model age from the different proxies used, which can be due to different tuning models or to different radiocarbon date calibrations. Nonetheless, when considering the different uncertainties in each age model, the different records can be reconciled. Indeed, dry conditions prevailing during the Younger-Dryas could be observed in the Blanchard Cave record if the errors on the age model are taken into account (Fig. 6). Similarly, the weak amount of age control points around the Heinrich event 2 do not allow us to conclude that Blanchard Cave record differs from other Caribbean and South American records. Heinrich events 1, 3 and 4 are relatively consistent between records. When more arid conditions are observed at Blanchard Cave, Cariaco Basin and Petén Itzá, more humid conditions are experienced at Botuverà cave (Fig. 6). This suggests that the Blanchard Cave record is a robust proxy of past ITCZ migration.

The ITCZ migration is driven by changes in the hemispheric temperature gradients. During abrupt events associated to HEs, the reduction of the AMOC (Bard et al., 2000) affected the displacement of the ITCZ southward, reinforcing trade wind and increasing both the temperature and salinity of the tropical Atlantic surface waters due to a reduced marine heat export northward (Chiang et al., 2002; Donders et al., 2011; Arbuszewski et al., 2013; Came et al., 2013). Since many years, teleconnections between polar and tropical latitudes have been investigated (e.g. Peterson et al., 2000; Deplazes et al., 2013), questioning the role played by millennial variations in North Atlantic climate on climate from lower latitudes. Recently, Rama-Corredor et al. (2015) have showed that Uk'37-SST $\left({ }^{\circ} \mathrm{C}\right)$ measurements from MD03-2616 core, located in Guiana Basin, covaried with the temperature changes observed in Greenland during interglacial periods. On a contrary, they showed a lack of synchrony during glacial periods, suggesting an Arctic-tropical decoupling when a substantial reduction in the AMOC takes place. MD03-2616 is located in the confluence of Northern (NEC) and Southern Hemisphere waters (NBC, SEC) suggesting a stronger influence of southern Hemisphere waters during glacial periods. When comparing with another tropical region, it is remarkable that variations in carbon isotope compositions from the Blanchard Cave are relatively similar to those observed in a Bromine $(\mathrm{Br})$ stack obtained by XRF counts from six sedimentary marine sediment cores located in the Arabian Sea (Fig. 7) (Caley et al., 2013). Brominated organic compounds in marine sediments are connected to primary producers (macroalgae) and heterotrophic organisms, with variations in the Bromine counts considered as proxies of marine organic carbon (productivity) changes (Ziegler et al., 2008). Caley et al. (2013) suggested that the Bromine stack could be related to the Indian monsoon. The India monsoon and associated position of the ITCZ reflect a bi-polar influence with a Southern Hemisphere imprint during the glacial period and a more significant role of the Northern Hemisphere during the last deglaciation. Consequently, the close pattern observed between the carbon isotope compositions from the continental archive of the Blanchard Cave and Arabian Sea records could suggest that the Eastern Caribbean islands were also under the influence of bipolar temperature gradients that impacted the mean location of the ITCZ. Hodell et al. (2008) have already indicated that dry periods in Petén Itzá were generally associated with warmings in Antarctica (AIM) during MIS 3. A Southern Hemisphere imprint could be visible during the glacial period as suggested by the relative close agreement (considering model age uncertainties) between Blanchard Cave records and the ice core Antarctica record of EDML (Fig. 7). The significant abrupt variability observed in the Blanchard record therefore reflects past migration of the ITCZ driven by bipolar temperature gradients, a mechanism that also contributed to the ITCZ migration in west Africa (Weldeab, 2012) and Arabian sea.

\section{Conclusions}

Fossil bat guano has been accumulated between 40 and $10 \mathrm{ka}$ cal. BP in Blanchard Cave located on the island of Marie-Galante in the Eastern Caribbean. Carbon and nitrogen isotope compositions of this guano revealed this tropical region to have experienced overall drier, and above all, more variable environmental conditions during this period compared to present-days. More specifically, variations in the isotopic compositions of bat guano are here interpreted to reflect major changes in the Late Pleistocene vegetation. Relatively wet environmental conditions prevailed during the second part of MIS 3 and the beginning of MIS 2, even still drier than those of Holocene, while the final part of the LGM and the very beginning of the Late Glacial regionally form an arid maximum during a two to three millennium period from ca 16 to $13 \mathrm{ka}$ cal. BP. When considering uncertainties in the model age, the isotopic record of Blanchard Cave are relatively similar to those observed with known records from Caribbean and South American records, suggesting that abrupt variability observed in the Blanchard record therefore reflect past migration of the ITCZ. The similar pattern equally observed between Blanchard Cave record and Arabian sea records suggests that islands of the eastern Caribbean Basin were also under the influence of bipolar temperature gradients that impacted the mean location of the ITCZ with a Southern Hemisphere imprint during the glacial period and a more significant role of the Northern Hemisphere during the last deglaciation.

\section{Acknowledgments}

This study was conducted as a part of the CNRS BIVAAG Program with support from a European PO-FEDER grant 2007-2013 $\mathrm{n}^{\circ} 2 /$ 2.4/-33456, the Guadeloupe Regional Council, the DEAL of Guadeloupe, and the DAC of Guadeloupe. This is Past4Future contribution and the research presented here received funding from the European Union's Seventh Framework programme (FP7/ 2007-2013) under grant agreement $n^{0}$ 243908, "Past4Future. Climate change - Learning from the past climate". The authors would also like to thank P. Martinez, C. Hatté, S. Desprat, V. Hanquiez, E. Puech, M. Corbé and B. Gravina for their help. The authors would like to thank anonymous reviewers for their constructive remarks and improvements of the manuscript.

\section{Appendix A. Supplementary data}

Supplementary data related to this article can be found at http:// dx.doi.org/10.1016/j.quascirev.2016.11.010.

\section{References}

Ahn, J., Brook, E.J., 2008. Atmospheric $\mathrm{CO}_{2}$ and climate on millennial time scales during the last glacial period. Science 322, 83-85.

Amundson, R., Austin, A.T., Schuur, E.A.G., Yoo, K., Matzek, V., Kendall, C., Uebersax, A., Brenner, D., Baisden, W.T., 2003. Global patterns of the isotopic composition of soil and plant nitrogen. Glob. Biogeochem. Cycle 17, 1031. http:// dx.doi.org/10.1029/2002GB001903.

Arbuszewski, J.A., deMenocal, P.B., Cleroux, C., Bradtmiller, L., Mix, A., 2013. Meridional shifts of the Atlantic intertropical convergence zone since the Last Glacial Maximum. Nat. Geosci. 6, 959-962.

Arens, N.C., Jahren, A.H., Amundson, R., 2000. Can C3 plants faithfully record the carbon isotopic composition of atmospheric carbon dioxide? Paleobiology 26, $137-164$.

Bailon, S., Bochaton, C., Lenoble, A., 2015. New data on Pleistocene and Holocene herpetofauna of Marie Galante (Blanchard Cave, Guadeloupe Islands, French West Indies): insular faunal turnover and human impact. Quat. Sci. Rev. 128, 127-137.

Barbotin, M., 1987. Archéologie antillaise: Arawaks et Caraïbes. Parc naturel de 
Guadeloupe.

Bard, E., Rostek, F., Turon, J.-L., Gendreau, S., 2000. Hydrological impact of Heinrich events in the subtropical northeast Atlantic. Science 289, 1321-1324.

Barnola, J.M., Raynaud, D., Korotkevich, Y.S., Lorius, C., 1987. Vostok ice core provides 160,000-year record of atmospheric $\mathrm{CO}_{2}$. Nature $329,408-414$.

Beets, C.J., Troelstra, S.R., Grootes, P.M., Nadeau, M.J., Borg, K.V., de Jong, A.F.M., Hofman, C.L., Hoogland, M.L.P., 2006. Climate and pre-Columbian settlement at Anse à la Gourde, Guadeloupe, Northeastern Caribbean. Geoarchaeology 21, 271-280.

Bender, M.M., 1971. Variation in the ${ }^{13} \mathrm{C} /{ }^{12} \mathrm{C}$ ratios of plants in relation to the pathway of photosynthetic carbon dioxide fixation. Phytochem 10, 1234-1244.

Bertran, P., Bonnissent, D., Imbert, D., Lozouet, P., Serrand, N., Stouvenot, C., 2004. Paléoclimat des Petites Antilles depuis 4000 ans BP: l'enregistrement de la lagune de Grand-Case à Saint-Martin. C. R. Geosci. 336, 1501-1510.

Bird, M.I., Boobyer, E.M., Bryant, C., Lewis, H.A., Paz, V., Stephens, W.E., 2007. A long record of environmental change from bat guano deposits in Makangit Cave, Palawan, Philippines. Earth Environ. Sci. T. Roy. Soc. Edinb. 98, 59-69.

Blaauw, M., 2010. Methods and code for "classical'age-modelling of radiocarbon sequences. Quat. Geochronol. 5, 512-518.

Blunier, T., Brook, E.J., 2001. Timing of millennial-scale climate change in Antarctica and Greenland during the last glacial period. Science 291, 109-112.

Bochaton, C., Grouard, S., Cornette, R., Ineich, I., Lenoble, A., Tresset, A., Bailon, S., 2015. Fossil and subfossil herpetofauna from cadet 2 cave (Marie-Galante, Guadeloupe Islands, F. W. I.): evolution of an insular herpetofauna since the Late Pleistocene. C. R. Palevol 14, 101-110.

Bond, G., Broecker, W., Johnsen, S., McManus, J., Labeyrie, L., Jouzel, J., Bonani, G., 1993. Correlations between climate records from North Atlantic sediments and Greenland ice. Nature 365, 143-147.

Bond, R.M., Seaman, G.A., 1958. Notes on a colony of Brachyphylla cavernarum. J. Mammal. 39, 150-151.

Bouysse, P., Garrabé, F., Mauboussin, T., Andreieff, P., Batistini, R., Carlier, P., Hinschberger, F., Rodet, J., 1993. Carte géologique département de la Guadeloupe. BRGM, Orléans.

Breuil, M., Masson, D., 1991. Quelques remarques sur la biogeographie des chauvessouris des Petites Antilles. C. R. Soc. Biogéogr. 67, 25-39.

Broccoli, A.J., Dahl, K.A., Stouffer, R.J., 2006. Response of the ITCZ to Northern Hemisphere cooling. Geophys. Res. Lett. 33, L01702.

Bush, M., Correa-metrio, A., Hodell, D., Brenner, M., Anselmetti, F., Ariztegui, D., Mueller, A., Curtis, J., Grzesik, D., Burton, C., Gilli, A., 2009. Re-evaluation of climate change in lowland Central America during the last glacial maximum using new sediment cores from Lake Petén Itzá, Guatemala. In: Vimeux, F., Sylvestre, F., Khodri, M. (Eds.), Past Climate Variability in South America and Surrounding Regions. Springer Netherlands, pp. 113-128.

Caley, T., Zaragosi, S., Bourget, J., Martinez, P., Malaizé, B., Eynaud, F., Rossignol, L., Garlan, T., Ellouz-Zimmermann, N., 2013. Southern Hemisphere imprint for Indo-Asian summer monsoons during the last glacial period as revealed by Arabian Sea productivity records. Biogeosciences 10, 7347-7359.

Came, R.E., Curry, W.B., Oppo, D.W., Broccoli, A.J., Stouffer, R.J., Lynch-Stieglitz, J., 2013. North Atlantic Intermediate Depth Variability during the Younger Dryas: Evidence from Benthic Foraminiferal Mg/Ca and the Gfdl R30 Coupled Climate Model, Ocean Circulation: Mechanisms and Impacts - Past and Future Changes of Meridional Overturning. American Geophysical Union, pp. 247-263.

Charles, C.D., Lynch-Stieglitz, J., Ninnemann, U.S., Fairbanks, R.G., 1996. Climate connections between the hemisphere revealed by deep sea sediment core/ice core correlations. Earth Planet. Sci. Lett. 142, 19-27.

Chiang, J.C.H., Kushnir, Y., Giannini, A., 2002. Deconstructing Atlantic Intertropical Convergence Zone variability: influence of the local cross-equatorial sea surface temperature gradient and remote forcing from the eastern equatorial Pacific. J. Geophys. Res. Atmos. 107. ACL 3-1-ACL 3-19.

Choa, O., Lebon, M., Gallet, X., Dizon, E., Ronquillo, W., Jago-on, S.C., Détroit, F., Falguères, C., Ghaleb, B., Sémah, F., 2016. Stable isotopes in guano: potential contributions towards palaeoenvironmental reconstruction in Tabon Cave, Palawan, Philipinnes. Quat. Int. 416, 27-37. http://dx.doi.org/10.1016/ j.quaint.2015.12.034.

Cleary, D.M., Onac, B.P., Forray, F.L., Wynn, J.G., 2016. Effect of diet, anthropogenic activity, and climate on $\delta^{15} \mathrm{~N}$ values of cave bat guano. Palaeogeo. Paleoclim. Paleoecol. 461, 87-97.

Curtis, J.H., Hodell, D.A., 1993. An isotopic and trace element study of ostracods from Lake Miragoane, Haiti: a 10,500 year record of paleosalinity and paleotemperature changes in the Caribbean. In: Swart, P.K., Lohmann, K.C., Mckenzie, J., Savin, S. (Eds.), Climate Change in Continental Isotopic Records. American Geophysical Union, pp. 135-152.

Dansgaard, W., Johnsen, S.J., Clausen, H.B., Dahl-Jensen, D., Gundestrup, N. Hammer, C.U., Hvidberg, C.S., Steffensen, J.P., Sveinbjornsdottir, A.E., Jouzel, J., Bond, G., 1993. Evidence for general instability of past climate from a 250-kyr ice-core record. Nature 364, 218-220.

Deplazes, G., Lückge, A., Peterson, L.C., Timmermann, A., Hamann, Y., Hughen, K.A., Röhl, U., Laj, C., Cane, M.A., Sigman, D.M., Haug, G.H., 2013. Links between tropical rainfall and North Atlantic climate during the last glacial period. Nat. Geosci. 6, 213-217.

De Niro, M.J., Epstein, S., 1981. Influence of diet on the distribution of nitrogen isotopes in animals. Geochim. Cosmochim. Acta 45, 341-351.

Des Marais, D.J., Mitchell, J.M., Meinschein, W.G., Hayes, J.M., 1980. The carbon isotope biogeochemistry of the individual hydrocarbons in bat guano and the ecology of the insectivorous bats in the region of Carlsbad, New Mexico.
Geochim. Cosmochim. Acta 44, 2075-2086.

Diefendorf, A.F., Mueller, K.E., Wing, S.L., Koch, P.L., Freeman, K.H., 2010. Global patterns in leaf ${ }^{13} \mathrm{C}$ discrimination and implications for studies of past and future climate. PNAS 107, 5738-5743.

Donders, T., de Boer, H., Finsinger, W., Grimm, E., Dekker, S., Reichart, G., WagnerCremer, F., 2011. Impact of the Atlantic Warm Pool on precipitation and temperature in Florida during North Atlantic cold spells. Clim. Dyn. 36, 109-118.

Ehleringer, J.R., Cerling, T.E., Helliker, B.R., 1997. C4 photosynthesis, atmospheric $\mathrm{CO}_{2}$, and climate. Oecologia 112, 285-299.

Emerson, J.K., Roark, A.M., 2007. Composition of guano produced by frugivorous, sanguivorous, and insectivorous bats. Acta Chiropterol. 9, 261-267.

Escobar, J., Hodell, D.A., Brenner, M., Curtis, J.H., Gilli, A., Mueller, A.D., Anselmetti, F.S., Ariztegui, D., Grzesik, D.A., Pérez, L., Schwalb, A. Guilderson, T.P., 2012. A 43-ka record of paleoenvironmental change in the Central American lowlands inferred from stable isotopes of lacustrine ostracods. Quat. Sci. Rev. 37, 92-104.

Farquhar, G.D., Ehleringer, J.R., Hubick, K.T., 1989. Carbon isotope discrimination and photosynthesis. Annu. Rev. Plant Biol. 40, 503-537.

Feng, X.H., Epstein, S., 1995. Carbon isotopes of trees from arid environments and implications for reconstructing atmospheric $\mathrm{CO}_{2}$ concentration. Geochim. Cosmochim. Acta 59, 2599-2608.

Fensterer, C., Scholz, D., Hoffmann, D.L., Spötl, C., Schröder-Ritzrau, A., Horn, C. Pajón, J.M., Mangini, A., 2013. Millennial-scale climate variability during the last 12.5 ka recorded in a Caribbean speleothem. Earth Planet. Sci. Lett. 361, $143-151$.

Forray, F.L., Onac, B.P., Tantau, B., Wynn, J.G., Tamas, T., Coroiu, I., Giurgiu, A., 2015. A Late Holocene environmental history of a bat guano deposit from Romania: an isotopic and pollen study. Quat. Sci. Rev. 127, 141-154. http://dx.doi.org/ 10.1016/j.quascirev.2015.05.022.

Gala, M., Lenoble, A., 2015. Evidence of the former existence of an endemic macaw in Guadeloupe, Lesser Antilles. J. Ornithol. 156, 1061-1066.

Gamble, D.W., Curtis, S., 2008. Caribbean precipitation: review, model and prospect. Prog. Phys. Geogr. 32, 265-276.

Gamble, D.W., Parnell, D.B., Curtis, S., 2008. Spatial variability of the Caribbean midsummer drought and relation to north Atlantic high circulation. Int. J. Climatol. $28,343-350$.

Gázquez, F., Calaforra, J.M., Stoll, H., Sanna, L., Forti, P., Lauritzen, S.E., Delgado, A., Rull, F., Martínez-Frías, J., 2013. Isotope and trace element evolution of the Naica aquifer (Chihuahua, Mexico) over the past 60,000 yr revealed by speleothems. Quat. Res. 80, 510-521.

Giannini, A., Cane, M.A., Kushnir, Y., 2001. Interdecadal changes in the ENSO teleconnection to the Caribbean Region and the North Atlantic Oscillation. J. Clim. 14, 2867-2879.

Giannini, A., Kushnir, Y., Cane, M.A., 2000. Interannual variability of Caribbean rainfall, ENSO, and the Atlantic Ocean. J. Clim. 13, 297-311.

González, C., Dupont, L.M., Behling, H., Wefer, G., 2008. Neotropical vegetation response to rapid climate changes during the last glacial period: palynological evidence from the Cariaco Basin. Quat. Res. 69, 217-230.

Goodfriend, G.A., Mitterer, R.M., 1988. Late quaternary land snails from the north coast of Jamaica: local extinctions and climatic change. Palaeogeo. Paleoclim. Paleoecol. 63, 293-311.

Grauel, A.L., Hodell, D.A., Bernasconi, S.M., 2016. Quantitative estimates of tropical temperature change in lowland Central America during the last 42 ka. Earth Planet. Sci. Lett. 438, 37-46.

Grouard, S., Bonnissent, D., Courtaud, P., Fouéré, P., Lenoble, A., Richard, G., Romon, T., Serrand, N., Stouvenot, C., 2013. Fréquentation amérindienne des cavités des Petites Antilles. In: $24 \mathrm{e}$ Congrès de l'asociation internationale des Archéologues de la caraïbe, pp. 277-295.

Handley, L.L., Austin, A.T., Stewart, G.R., Robinson, D., Scrimgeour, C.M., Raven, J.A Schmidt, S., 1999. The ${ }^{15} \mathrm{~N}$ natural abundance $\left(\delta^{15} \mathrm{~N}\right)$ of ecosystem samples reflects measures of water availability. Funct. Plant Biol. 26, 185-199.

Hatté, C., Rousseau, D.D., Guiot, J., 2009. Climate reconstruction from pollen and $\delta^{13} \mathrm{C}$ records using inverse vegetation modeling - implication for past and future climates. Clim. Past. 5, 147-156.

Haug, G.H., Hughen, K.A., Sigman, D.M., Peterson, L.C., Röhl, U., 2001. Southward migration of the intertropical convergence zone through the Holocene. Science 293, 1304-1308.

Herrera, L.G., Gerardo, L., Hobson, K.A., Manzo, A., Estrada, B., Sánchez-Cordero, V. Méndez, C., 2001a. The role of fruits and insects in the nutrition of frugivorous bats: evaluating the use of stable isotope models 1. Biotropica 33, 520-528.

Herrera, L.G., Hobson, K.A., Leticia, M.M., Ramírez, P.N., Méndez, C.G., SánchezCordero, V., 2001b. Sources of protein in two species of phytophagous bats in a seasonal dry forest: evidence from stable-isotope analysis. J. Mammal. 82, 352-361.

Higuera-Gundy, A., Brenner, M., Hodell, D.A., Curtis, J.H., Leyden, B.W. Binford, M.W., 1999. A $10,300{ }^{14} \mathrm{C}$ yr record of climate and vegetation change from Haiti. Quat. Res. 52, 159-170.

Hodell, D.A., Anselmetti, F.S., Ariztegui, D., Brenner, M., Curtis, J.H., Gilli, A., Grzesik, D.A., Guilderson, T.J., Müller, A.D., Bush, M.B., 2008. An 85-ka record of climate change in lowland Central America. Quat. Sci. Rev. 27, 1152-1165.

Hodell, D.A., Curtis, J.H., Jones, G.A., Higuera-Gundy, A., Brenner, M., Binford, M.W., Dorsey, K.T., 1991. Reconstruction of Caribbean climate change over the past 10,500 years. Nature $352,790-793$.

Holmes, J.A., 1998. A late Quaternary ostracod record from Wallywash Great Pond, a Jamaican marl lake. J. Paleolimnol. 19, 115-128. 
Keeling, C.D., Piper, S.C., Bacastow, R.B., Wahlen, M., Whorf, T.P., Heimann, M., Meijer, H.A., 2005. Atmospheric $\mathrm{CO}_{2}$ and ${ }^{13} \mathrm{CO}_{2}$ Exchange with the Terrestrial Biosphere and Oceans from 1978 to 2000: Observations and Carbon Cycle Implications, a History of Atmospheric $\mathrm{CO}_{2}$ and its Effects on Plants, Animals, and Ecosystems. Springer, pp. 83-113.

Kelly, J.F., 2000. Stable isotopes of carbon and nitrogen in the study of avian and mammalian trophic ecology. Can. J. Zool. 78, 1-27.

Kohn, M.J., 2010. Carbon isotope compositions of terrestrial C3 plants as indicators of (paleo)ecology and (paleo)climate. PNAS 107, 19691-19695.

Kolb, K.J., Evans, R.D., 2002. Implications of leaf nitrogen recycling on the nitrogen isotope composition of deciduous plant tissues. New Phytol. 156, 57-64.

Lachniet, M.S., Asmerom, Y., Burns, S.J., Patterson, W.P., Polyak, V.J., Seltzer, G.O. 2004. Tropical response to the $8200 \mathrm{yr}$ BP cold event? Speleothem isotopes indicate a weakened early Holocene monsoon in Costa Rica. Geology 32, 957-960.

Lachniet, M.S., Asmerom, Y., Bernal, J.P., Polyak, V.J., Vazquez-Selem, L., 2013. Orbital pacing and ocean circulation-induced collapses of the Mesoamerican monsoon over the past 22,000 y. PNAS 110, 9255-9260.

Lane, C.S., Horn, S.P., Mora, C.I., Orvis, K.H., 2009. Late-Holocene paleoenvironmental change at mid-elevation on the Caribbean slope of the Cordillera Central, Dominican Republic: a multi-site, multi-proxy analysis. Quat. Sci. Rev. 28, 2239-2260.

Lasserre, G., 1961. La Guadeloupe: Étude Géographie. Union française d'impression.

Lea, D.W., Pak, D.K., Peterson, L.C., Hughen, K.A., 2003. Synchroneity of tropical and high-latitude Atlantic temperatures over the last glacial termination. Science 301, 1361-1364.

Lenoble, A., Angin, B., Huchet, J.-B., Royer, A., 2014. Seasonal insectivory of the Antillean fruit bat (Brachyphylla cavernarum). Carib. J. Sci. 48 (2-3), 127-131.

Lenoble, A., Queffelec, A., Bonnissent, D., Stouvenot, C., 2015. Rock art taphonomy in Lesser Antilles: study of wall weathering and engravings preservation in two precolumbian caves on Marie-Galante Island. In: Proceedings of the 26th IACA Congress, Puerto Rico.

Lenoble, A., Stouvenot, C., Courtaud, P., Grouard, S., Scalliet, M., Serrand, N., 2009 Formes et remplissages du karst littoral guadeloupéen. In: Vanara, N. Orthez, Douat M. (Eds.), Le karst, indicateur performant des environnements passés et actuels. ICN, pp. 226-233.

Leuenberger, M., Siegenthaler, U., Langway, C., 1992. Carbon isotope composition of atmospheric $\mathrm{CO}_{2}$ during the last ice age from an Antarctic ice core. Nature 357, 488-490.

Leyden, B.W., 1995. Evidence of the younger dryas in Central America. Quat. Sci. Rev. $14,833-839$

Makarov, M.I., 2009. The nitrogen isotopic composition in soils and plants: its use in environmental studies (a review). Eurasian Soil Sci. 42, 1335-1347.

Malaizé, B., Bertran, P., Carbonel, P., Bonnissent, D., Charlier, K., Galop, D., Imbert, D. Serrand, N., Stouvenot, C., Pujol, C., 2011. Hurricanes and climate in the Caribbean during the past 3700 years BP. Holocene 21, 911-924.

Masson, D., Breuil, M., Breuil, A., 1990. Premier inventaire des chauves-souris de l'île de Marie-Galante (Antilles françaises). Mammalia 54, 656-658.

McCarthy, T.J., Henderson, R.W., 1992. Confirmation of Ardops nichollsi on MarieGalante, Lesser Antilles, and comments on other bats. Carib. J. Sci. 28 (1-2) 106-107.

McFarlane, D.A., Lundberg, J., Fincham, A.G., 2002. A late Quaternary paleoecological record from caves of southern Jamaica, West Indies. J. Cave Karst Stud. 64, $117-125$.

Mizutani, H., Wada, E., 1988. Nitrogen and carbon isotope ratios in seabird rookeries and their ecological implications. Ecology 69, 340-349.

Mizutani, H., McFarlane, D.A., Kabaya, Y., 1992a. Carbon and nitrogen isotopic signatures of bat guanos as record of past environments. J. Mass. Spectrom. Soc. Jap 40, 67-82.

Mizutani, H., McFarlane, D.A., Kabaya, Y., 1992b. Nitrogen and carbon isotope study of bat guano core from Eagle Creek Cave, Arizona, USA. J. Mass. Spectrom. Soc. Jap. 40, 57-65.

Morrison, D.W., 1980. Efficiency of food utilization by fruit bats. Oecologia 45, $270-273$.

Murphy, B.P., Bowman, D.M.J.S., 2006. Kangaroo metabolism does not cause the relationship between bone collagen $\delta^{15} \mathrm{~N}$ and water availability. Funct. Ecol. 20, 1062-1069.

Murphy, B.P., Bowman, D.M.J.S., 2009. The carbon and nitrogen isotope composition of Australian grasses in relation to climate. Funct. Ecol. 23, 1040-1049.

North Greenland Ice Core Project, 2004. High-resolution record of Northern Hemisphere climate extending into the last interglacial period. Nature 431 $147-151$

Onac, B.P., Forray, F.L., Wynn, J.G., Giurgiu, A.M., 2014. Guano-derived $\delta^{13}$ C-based paleo-hydroclimate record from Gaura cu Musca Cave, SW Romania. Environ. Earth Sci. 71, 4061-4069.

Onac, B.P., Hutchison, S.M., Geanta, A., Forray, F.L., Wynn, J.G., Giurgiu, A.C., Coroiu, I., 2015. A 2500-year Late Holocene multi-proxy record of vegetation and hydrologic changes from a cave guano-clay sequence in SW Romania. Quat. Res. 83, 437-448. http://dx.doi.org/10.1016/j.ypres.2015.01.007.

Painter, M.L., Chambers, C.L., Siders, M., Doucett, R.R., Whitaker, J.J.O., Phillips, D.L. 2009. Diet of spotted bats (Euderma maculatum) in Arizona as indicated by fecal analysis and stable isotopes. Can. J. Zool. 87, 865-875.

Pérez, L., Frenzel, P., Brenner, M., Escobar, J., Hoelzmann, P., Scharf, B., Schwalb, A. 2011. Late Quaternary (24-10 ka BP) environmental history of the Neotropical lowlands inferred from ostracodes in sediments of Lago Petén Itzá, Guatemala.
J. Paleolimnol. 46, 59-74.

Peterson, L.C., Haug, G.H., 2006. Variability in the mean latitude of the Atlantic Intertropical Convergence Zone as recorded by riverine input of sediments to the Cariaco Basin (Venezuela). Palaeogeo. Paleoclim. Paleoecol. 234, 97-113.

Peterson, L.C., Haug, G.H., Hughen, K.A., Röhl, U., 2000. Rapid changes in the hydrologic cycle of the tropical Atlantic during the last glacial. Science 290, 1947-1951.

Portecop, J., 1982. Végétation, Atals des Départements français d'Outre-Mer.III. La Guadeloupe. CNRS, Paris.

Pregill, G.K., Olson, S.L., 1981. Zoogeography of West Indian vertebrates in relation to Pleistocene climatic cycles. Annu. Rev. Ecol. Syst. 12, 75-98.

Pregill, G.K., Steadman, D.W., Watters, D.R., 1994. Late Quaternary Vertebrate Faunas of the Lesser Antilles: Historical Components of Carribbean Biogeography. Carnegie Museum of Natural History.

Prentice, I.C., Harrison, S.P., 2009. Ecosystem effects of $\mathrm{CO}_{2}$ concentration: evidence from past climates. Clim. Past. 5, 297-307. http://dx.doi.org/10.5194/cp-5-2972009.

R Development Core Team, 2008. R: a Language and Environment for Statistical Computing. Vienna, Austria. http://www.R-project.org.

Rama-Corredor, O., Martrat, B., Grimalt, J.O., López-Otalvaro, G.E., Flores, J.A. Sierro, F., 2015. Parallelisms between sea surface temperature changes in the western tropical Atlantic (Guiana Basin) and high latitude climate signals over the last 140000 years. Clim. Past. 11, 1297-1311.

Reimer, P., Bard, E., Bayliss, A., Beck, J., Blackwell, P., Bronk Ramsey, C., Buck, C., Cheng, H., Edwards, R., Friedrich, M., Grootes, P., Guilderson, T., Haflidason, H., Hajdas, I., Hatté, C., Heaton, T., Hoffmann, D., Hogg, A., Hughen, K., Kaiser, K., Kromer, B., Manning, S., Niu, M., Reimer, R., Richards, D., Scott, E., Southon, J., Staff, R., Turney, C., Van der Plicht, J., 2013. IntCal13 and Marine13 radiocarbon age calibration curves $0-50,000$ years cal BP. Radiocarbon 55, 1869-1887.

Rodet, J., 1987. La spéléologie des îles calcaires de la Grande-Terre et de MarieGalante. In: Actes du 8e Congrès national de la Société Suisse de Spéléologie, Société Suisse de Spéléologie et Commission de Spéléologie de la Société Helvétique des Sciences Naturelles, Turgi. département de la Guadeloupe, Petites Antilles, France, pp. 227-236.

Rodríguez-Durán, A., 2010. Bat assemblages in the West Indies: the role of caves. In: Fleming, T.H., Racey, P.A. (Eds.), Island Bats: Evolution, Ecology and Conservation. The University of Chicago Press, Chicago (IL), pp. 265-280.

Rousteau, A., Portecop, J., Rollet, B., 1996. Carte écologique de la Guadeloupe. ONF, UAG, PNG, CGG, Jarry, Guadeloupe.

Royer, A., Queffelec, A., Charlier, K., Puech, E., Malaizé, B., Lenoble, A., 2015. Seasonal changes in stable carbon and nitrogen isotope compositions of bat guano (Guadeloupe). Palaeogeo. Paleoclim. Paleoecol. 440, 524-532.

Salvarina, I., Yohannes, E., Siemers, B.M., Koselj, K., 2013. Advantages of using fecal samples for stable isotope analysis in bats: evidence from a triple isotopic experiment. Rapid Commun. Mass Spectrom. 27, 1945-1953.

Schmidt, M.W., Chang, P., Hertzberg, J.E., Them, T.R., Ji, L., Otto-Bliesner, B.L., 2012. Impact of abrupt deglacial climate change on tropical Atlantic subsurface temperatures. PNAS 109, 14348-14352.

Schmidt, M.W., Spero, H.J., Lea, D.W., 2004. Links between salinity variation in the Caribbean and North Atlantic thermohaline circulation. Nature 428, 160-163.

Schmitt, J., Schneider, R., Elsig, J., Leuenberger, D., Lourantou, A., Chappellaz, J., Köhler, P., Joos, F., Stocker, T.F., Leuenberger, M., 2012. Carbon isotope constraints on the deglacial $\mathrm{CO}_{2}$ rise from ice cores. Science 336, 711-714.

Smith, B.N., Epstein, S., 1971. Two categories of ${ }^{13} \mathrm{C} /{ }^{12} \mathrm{C}$ ratios for higher plants. Plant Physiol. 47, 380-384.

Smith, B.N., Oliver, J., Mc Millan, C., 1976. Influence of carbon source, oxygen concentration, light intensity, and temperature on ${ }^{13} \mathrm{C} /{ }^{12} \mathrm{C}$ ratios in plant tissues. Bot. Gaz. 137, 99-104.

Soto-Centeno, J.A., Phillips, D.L., Kurta, A., Hobson, K.A., 2014. Food resource partitioning in syntopic nectarivorous bats on Puerto Rico. J. Trop. Ecol. 1-11.

Soto-Centeno, J.A., Rodriguez-Durán, A., Cortes, E., 2001. Erophylla sezekorni and Brachyphylla cavernarum diet of two Phyllostomid bats in Puerto Rico. Bat Res. News 42, 180-181.

Stevens, R.E., Hermoso-Buxán, X.L., Marín-Arroyo, A.B., González-Morales, M.R., Straus, L.G., 2014. Investigation of Late Pleistocene and Early Holocene palaeoenvironmental change at El Mirón cave (Cantabria, Spain): insights from carbon and nitrogen isotope analyses of red deer. Palaeogeo. Paleoclim. Paleoecol. 414, 46-60.

Stevens, R.E Jacobi, R. Street, M. Germonpré, M. Conard, N. Münzel, S.C. Hedges, R.E.M., 2008. Nitrogen isotope analyses of reindeer (Rangifer tarandus), 45,000 BP to 9,000 BP: palaeoenvironmental reconstructions. Palaeogeo. Paleoclim. Paleoecol. 262, 32-45.

Stoetzel, E., Royer, A., Cochard, D., Lenoble, A., 2016. Late Quaternary changes in Bat palaeobiodiversity and palaeobiogeography under climatic and anthropogenic pressure: new insights from Marie-Galante, Lesser Antilles. Quat. Sci. Rev. 143, 150-174.

Stouffer, R.J., Yin, J., Gregory, J.M., Dixon, K.W., Spelman, M.J., Hurlin, W., Weaver, A.J., Eby, M., Flato, G.M., Hasumi, H., Hu, A., Jungclaus, J.H., Kamenkovich, I.V, Levermann, A Montoya, M., Murakami, S, Nawrath, S. Oka, A., Peltier, W.R., Robitaille, D.Y., Sokolov, A., Vettoretti, G., Weber, S.L., 2006. Investigating the causes of the response of the thermohaline circulation to past and future climate changes. J. Clim. 19, 1365-1387.

Stouvenot, C., 2003. Cavités Naturelles Dans L'archipel Guadeloupéen. Prospection Thématique 2003. SRA DRAC Guadeloupe.

Stouvenot, C., 2005. Capesterre de Marie-Galante. Grotte Blanchard. Notice 
scientifique page 28, Bilan scientifique 2005 SRA Guadeloupe. Direction Régionale des Affaires Culturelles de Guadeloupe, Basse-Terre Guadeloupe.

Street-Perrott, F.A., Hales, P.E., Perrott, R.A., Fontes, J.C., Switsur, V.R., Pearson, A., 1993. Late quaternary palaeolimnology of a tropical marl lake: Wallywash Great Pond, Jamaica. J. Paleolimnol. 9, 3-22.

Teeri, J.A., Stowe, L.G., 1976. Climatic patterns and the distribution of C4 grasses in North America. Oecologia 23, 1-12.

Tieszen, L.L., Reed, C.B., Bliss, N.B., Wylie, B.K., Delong, D.D., 1997. NDVI, C3 and C4 production, and distributions in Great Plains grassland land cover classes. Ecol. Appl. 7, 59-78.

Van de Water, P.K., Leavitt, S.W., Betancourt, J.L., 1994. Trends in stomatal density and ${ }^{13} \mathrm{C} /{ }^{12} \mathrm{C}$ ratios of Pinus flexilis needles during Last Glacial-Interglacial cycle. Science 264, 239-243.

Wang, Y.J., Cheng, H., Edwards, R.L., An, Z.S., Wu, J.Y., Shen, C.-C., Dorale, J.A., 2001. A high-resolution absolute-dated late Pleistocene monsoon record from Hulu Cave, China. Science 294, 2345-2348.

Wang, X., Auler, A.S., Edwards, R.L., Cheng, H., Ito, E., Wang, Y., Kong, X., Solheid, M., 2007. Millennial-scale precipitation changes in southern Brazil over the past 90,000 years. Geophys. Res. Lett. 34 http://dx.doi.org/10.1029/2007GL031149.

Widga, C., Colburn, M., 2015. Paleontology and paleoecology of guano deposits in Mammoth Cave, Kentucky, USA. Quat. Res. 83, 427-436.

Weldeab, S., 2012. Bipolar modulation of millennial-scale West African monsoon variability during the last glacial (75,000-25,000 years ago). Quat. Sci. Rev. 40 21-29.

Wurster, C.M., McFarlane, D.A., Bird, M.I., 2007. Spatial and temporal expression of vegetation and atmospheric variability from stable carbon and nitrogen isotope analysis of bat guano in the southern United States. Geochim. Cosmochim. Acta 71, 3302-3310.

Wurster, C.M., Patterson, W.P., McFarlane, D.A., Wassenaar, L.I., Hobson, K.A. Athfield, N.B., Bird, M.I., 2008. Stable carbon and hydrogen isotopes from bat guano in the Grand Canyon, USA, reveal Younger Dryas and 8.2 ka events. Geology 36, 683-686.

Wurster, C.M., Bird, M.I., Bull, I.D., Creed, F., Bryant, C., Dungait, J.A., Paz, V., 2010a. Forest contraction in north equatorial Southeast Asia during the last Glacial Period. PNAS 107, 15508-15511.

Wurster, C.M., McFarlane, D.A., Bird, M.I., Ascough, P.I., Athfield, N.B., 2010b. Stable isotopes of subfossil bat guano as a long-term environmental archive: insights from a Grand Canyon cave deposit. J. Cave Karst Stud. 72, 111-121.

Yanes, Y., Romanek, C.S., 2013. Quaternary interglacial environmental stability in San Salvador Island (Bahamas): a land snail isotopic approach. Palaeogeo. Paleoclim. Paleoecol. 369, 28-40.

Ziegler, M., Jilbert, T., de Lange, G.J., Lourens, L.J., Reichart, G., 2008. Bromine counts from XRF scanning as an estimate of the marine organic carbon content of sediment cores. Geochem. Geophy. Geosy. 9, Q05009. 